\title{
THE INFLUENCE OF WAGES AND \\ INDUSTRIAL RELATIONS ENVIRONMENTS ON THE PRODUCTION LOCATION DEGISIONS OF U.S. MULTINATIONAL CORPORATIONS
}

\author{
MARIO F. BOGNANNO, MICHAEL P. KEANE, and DONGHOON YANG*
}

\begin{abstract}
Using the Benchmark and Annual Surveys of U.S. Direct Investment Abroad collected by the Bureau of Economic Analysis, the authors examine the operations of U.S. multinational corporations (MNCs) in seven manufacturing industries and twenty-two countries over the years 1982-91. They analyze how tariffs, wages, and industrial relations environments influenced U.S. MNCs' decisions about where to locate assets and employment. The results imply that wages and the industrial relations environment were statistically significant determinants of the extent to which MNCs located operations in a particular host country. However, while these factors were important, their impact was much smaller than that of host country market size, which was by far the main determinant of MNC location decisions. Furthermore, the authors find no evidence that tariff reductions increased the share of U.S. MNC activities located abroad. Thus, concerns that tariff reductions may lead to loss of "American jobs" appear to be exaggerated.
\end{abstract}

$\mathbf{H}$ ow multinational corporations (MNCs) decide where to locate production has been a subject of considerable interest in recent years. For example, in the debate over the North American Free

\footnotetext{
* Mario Bognanno is Professor in the Industrial Relations Center, University of Minnesota; Michael Keane is Professor of Economics, Yale University; and Donghoon Yang is an Associate Professor in the School of Business at Sogang University in Seoul, South Korea. For helpful comments, the authors thank seminar and conference participants at the Department of Economics, University of Le Havre, France; the Industrial Relations Research Association; the Korea Development Institute, Seoul; and the Industrial Relations Center (IRC), University of Minnesota.
}

Trade Agreement (NAFTA), U.S. labor unions and many politicians, as well as some academics, expressed concern that trade liberalization would cause U.S. MNCs to move production facilities from the United States to Mexico, so as to take advantage of lower Mexican wages. ${ }^{1}$ The basic logic is

The data and computer programs used in this study are available on request from Donghoon Yang (dhyang@mail.sogang.ac.kr).

${ }^{1}$ For instance, a spokesman for the AFL-CIO stated, "A new trade agreement with Mexico . . . will only encourage greater capital outflows from the United States, bring about an increase in imports from Mexico, and reduce domestic employment" (see Anderson 1993:55). See also Betcherman (1993) or Robinson (1994). 
that in the absence of U.S. tariffs, it would in many instances be optimal for U.S. firms to produce in Mexico, where labor costs are lower, and then to ship finished products back to the United States for sale. According to this view, U.S. tariff walls provide an important incentive for corporations to produce within the United States those goods intended for final sale in the United States.

This raises the empirical question of just how tariffs and cross-country wage differentials affect the production location decisions of MNCs. Production location decisions include how to allocate capital and employment across countries, how much output to produce in each country, and the volumes of goods to ship between countries. There now exists a large literature on the factors that influence MNCs' foreign direct investment (FDI), employment, and production in various countries. Interestingly, this work has typically found that host country wages either are not a statistically significant determinant of MNCs' production location decisions or are a statistically significant determinant but with the "wrong" sign. That is, conditional on other control variables, the correlation between the amount of capital, employment, or production MNCs locate in a country, and the average wage rate in the country, is usually found to be essentially zero or even positive (see, for example, Swedenborg 1979; Dunning 1980; Cooke 1997; Cooke and Noble 1998). ${ }^{2}$

Findings of zero or positive correlations between MNC investments and wage rates across countries have been viewed as anomalous given the widespread expectation that, ceteris paribus, returns on investment should be greater in countries with lower labor costs. There are at least four potential explanations for this anomalous finding. First, if MNC organization is primarily "horizontal" rather than "vertical," meaning that

${ }^{2}$ Of course, conditional on an MNC having chosen to operate in a country, a positive wage effect on capital can be easily rationalized, provided the substitution effect dominates the scale effect. most FDI is driven by market access considerations (rather than the desire to exploit factor price differentials), we would expect to see most FDI in large markets (that is, industrialized high-wage countries).

A second possibility is that, if labor quality is much lower in low-wage countries, then wages per efficiency unit of labor may be relatively high in such countries. Third, unobserved (or unmeasured) characteristics of countries that make them attractive places in which to invest (such as favorable factor endowments, low corruption, or openness to FDI) may be positively correlated with wage rates. In the second and third scenarios, the effect of the wage per efficiency unit of labor on the attractiveness of a country as a production location is in fact negative, but omitted variables may lead to bias in the regression estimates of the true effect.

A fourth possibility is that average wages in foreign countries are not relevant for MNC production location decisions. An MNC that uses a particular technology in its production process may require workers with particular skills. In that case, even if the average wage rate in a country is low, the wage rate among the relevant set of workers with the necessary skills to implement the production process may be high.

Under this fourth scenario, it may make sense to view U.S. MNCs not as wage takers in competitive labor markets in each host country, but rather as bargaining over wages with the set of workers possessing the necessary skills to operate their production processes. In that case, the attractiveness of a host country may be influenced by features of its industrial relations (IR) environment that affect bargaining outcomes, such as union power and collective bargaining structure. Indeed, Ulman (1975) and Carlton (1979) argued that firms avoid investment in locations where unions are powerful, independent of the wage rate. A key objective of this paper is to evaluate whether features of the IR environment are in fact important determinants of MNC production location decisions.

Our paper contributes to the literature by using industry-level panel data to exam- 
ine U.S. MNCs' production location decisions. Specifically, we use data on the operations of U.S. MNCs in seven manufacturing industries and twenty-two foreign countries over the years 1982-91. The data are from the Benchmark and Annual Surveys of U.S. Direct Investment Abroad collected by the Bureau of Economic Analysis (BEA), plus a number of additional data sources that we have merged with the BEA data. In contrast, most previous work in this area has used crosssectional data on MNC activities in a single year, or used data aggregated to the national level.

For example, a paper to which ours is closely related is that by Grubert and Mutti (1991a), who found, using data from the BEA's 1982 Benchmark survey aggregated to the national level, that both corporate tax rates and tariffs are important determinants of U.S. MNCs' production location decisions (they did not, however, examine the influence of wages or IR factors). Another related paper that used country-level panel data, Kleiner and Ham (2003), reported evidence that more "progressive" IR systems do reduce FDI flows. As we discuss below, however, there are important reasons to examine FDI levels as well as flows. The papers by Cooke (1997), Cooke and Noble (1998), and Cooke (2001) used cross-sectional data at the country/industry level, and found evidence that IR systems affect the allocation of MNC assets across countries. To our knowledge, our paper is the first to use industry-level panel data to address these issues.

The use of industry-level panel data to study FDI is desirable for two reasons. First, panel data enable one to exploit the temporal co-variation (within industries) between FDI and the covariates of interest in order to better identify the effects of those covariates (that is, these data provide information beyond that in the cross-sectional co-variation).

Second, there are likely to be unobserved (or unmeasured) characteristics of particular countries that make them attractive as locations for particular industries. Ex- amples are countries' factor endowments, ${ }^{3}$ as well as differences in worker quality that are not captured by observed characteristics of the labor force. But we are interested in how certain "generic country factors," such as wages and features of the IR environment, affect MNC production location decisions. If such generic factors are correlated with unmeasured country characteristics, then failure to control for country/industry effects will lead to inconsistent estimates of wage and IR effects. One needs industry-level panel data to implement such controls.

As will become apparent when we present our results, we find that controlling for industry- and country-specific unobservables using panel data techniques does indeed lead to more reasonable estimates of wage and other effects on MNC production location decisions than have been obtained in prior work. This highlights the importance of using industry-level panel data to study these questions.

\section{Theoretical and Empirical Literatures on MNG Behavior}

To guide our empirical specifications, we turn to the theoretical literature on MNC behavior. Markusen and Maskus (2001, 2002) provide an excellent overview of the current state of the literature. They divide theories of the MNC into those that generate "vertical" versus "horizontal" MNCs. Vertical MNCs fragment the production process across countries to take advantage of factor price differentials, for example, by locating unskilled labor-intensive parts of the process in low-wage countries. Horizontal MNCs basically replicate the entire production process in multiple countries, thus avoiding tariff and transport costs. ${ }^{4}$

${ }^{3}$ For example, MNCs in the pulp, paper, and board mills industry would presumably invest heavily in Canada even if its business climate were not particularly attractive, simply because of its substantial timber endowment.

${ }^{4}$ Theories of the MNC originated in the international business literature, with the so-called "Owner- 
These theoretical models generate clear predictions for the set of variables we expect to have an important impact on FDI. The vertical models obviously imply that factor price differentials (wage differentials, for example) between potential host countries and the United States should be important. Vertical models also imply that tariffs (as well as geographic distance and transport costs) discourage FDI by preventing MNCs from exploiting factor price differentials. This predicted mechanism is consistent with the notion that trade liberalization could cost U.S. jobs.

In contrast, horizontal models imply that market size (that is, host country gross domestic product) is the main factor driving FDI, since market access is MNCs' main motivation. The horizontal models also imply that higher tariffs (and distance) should encourage FDI because they increase the advantage to locating production in the host country. Both vertical and horizontal models imply that variables affecting the cost of foreign operations (such as English language, cultural openness, local corruption, corporate taxes, and the IR environment) should matter.

As Markusen and Maskus point out, if U.S. MNCs direct most of their FDI toward

ship-Location-Internalization (OLI) paradigm"-see Hymer (1976) and Dunning (1975). In the OLI theory, in order to rationalize FDI, an MNC must have an "ownership advantage," such as a superior production process or a well-known brand name, which enables it to compete with foreign firms in their own markets (despite language barriers, communication and transport costs, and so on). The MNC must also have an "internalization advantage"-see Rugman (1985)—which makes FDI preferable to licensing. For example, a licensee might steal production process knowledge or dilute a brand name by skimping on quality. Finally, the MNC must possess a "location advantage" that makes FDI preferable to serving foreign markets via exports. In "horizontal" MNC models the location advantage arises from the desire to jump the tariff wall or save on transport costs, or because proximity to final customers is important (for example, to provide service). In contrast, in "vertical" MNC models, the main purpose of FDI is to fragment the production process across countries to exploit factor price differentials, so tariffs discourage FDI. large countries with factor prices similar to those in the United States, the horizontal model will be the better predictor of FDI patterns. But if most FDI is directed toward countries with very different factor prices (for example, lower wages), the vertical model is the better predictor. Since our goal is to focus on whether wages and IR factors have an important impact on FDI, without taking an a priori stand on whether the vertical or horizontal model is most appropriate, we simply include a rather complete set of control variables that might be relevant under one or the other model.

Feinberg and Keane (2003) presented an estimable structural model of MNC behavior that guides the reduced form empirical work here (as well as that in Feinberg, Keane, and Bognanno 1998 and Feinberg and Keane 2001). Their model considers an MNC with an affiliate in a single foreign country. The MNC chooses eight inputs, $\left\{K_{j}, L_{j}, M_{j}, N_{j}\right\}_{j=d, f}$, where $K, L, M, N$ denote capital, labor, raw materials, and intermediate inputs, respectively, and the $j=d, f$ subscript denotes whether the input is used in the parent (domestic) or affiliate (foreign) production process. The MNC also chooses a level of exports $(E)$ from the parent to the host country, and of imports (I) from the affiliate to the domestic market. The intermediate input $N_{d}$ denotes a part of the affiliate's output that is shipped back to the parent for further processing, and conversely for $N_{f}$. This model nests both the vertical and horizontal models of MNC organization. A purely horizontal MNC, for example, would have $N_{d}=N_{f}=E=$ $I=0$, so the affiliate production process replicates the parent's, all parent output is sold in the United States, and all affiliate output is sold in the host country.

The ten MNC choice variables, as well as any functions of those variables (like output or sales), are endogenous in the model. The MNC chooses these ten variables to maximize profits, given a set of constraints determined by the parent and affiliate production functions, the wage rate, prices of capital and materials, tariffs and transport costs, and four demand functions for the goods produced by the parent and affiliate 
(the domestic and foreign demands for the good produced by the parent, and the domestic and foreign demands for the good produced by the affiliate). The demand functions are shifted by domestic and foreign gross domestic product (GDP). Exchange rates enter the model implicitly by altering the relative factor prices and output prices in the two countries. Any variables that affect MNC behavior through the constraints are exogenous in the model.

Brainard (1995) also provided a useful discussion of which variables are viewed as exogenous in the dominant theoretical models of MNCs. These include transportation costs, tariffs, corporate tax rates, and measures of income and market size for the domestic and foreign markets. In the Feinberg and Keane (2003) structural model these variables are also exogenous, as are wages, the price of capital, ${ }^{5}$ and other factor input prices. Here we augment this list of assumed exogenous variables to include national-level IR environment variables, which we argue may affect the firm's labor costs. Additional factors entering through costs of doing business in a host country include English language proficiency, cultural openness, and corruption measures.

In this theoretical framework, the construction of a valid reduced form equation requires that one of the endogenous variables (or some function thereof) be regressed on the complete set of exogenous variables. In contrast, in the FDI literature, when authors have estimated equations in which the dependent variables are such

\footnotetext{
${ }^{5}$ We realize that in a richer model of capital investment decisions the price of capital is also endogenous, depending, for instance, on firm-specific capital adjustment costs, risk/return factors, and financial structure and how this interacts with taxes. Furthermore, in equilibrium the price of capital will be correlated with aggregate productivity shocks that are common to all firms. We abstract from this problem and simply control for aggregate-level determinants of the cost of capital, like interest rates and corporate tax rates, which are plausibly exogenous from the perspective of individual firms (that is, if productivity shocks are largely idiosyncratic).
}

quantities as MNCs' assets, sales, employment, or output in various host countries, they have commonly used as "explanatory" variables such quantities as capital/labor ratios, exports to the host country, $\mathrm{R} \& \mathrm{D}$ spending, advertising expenditure, and firm size. But such "explanatory" variables are jointly determined along with the MNCs' decisions about production location and, therefore, they are potentially endogenous.

The common practice of including measures of exports to a host country ( $E$ in our notation) as a predictor of the level of MNC assets located in that county $\left(K_{f}\right.$ in our notation) has been rationalized by the argument that exports are an alternative to FDI, and they therefore substitute for FDI. However, by analogy, to include exports on the right-hand side of a "reduced form" equation to predict FDI (that is, $K_{f}$ ) is no more appropriate than to include labor input on the right-hand side of an equation to predict demand for capital. Rather, a valid reduced form for FDI should include on the right the complete set of exogenous variables that may affect the cost of serving the foreign market via either FDI or exports. Examples of the former are wages and the corporate tax rate in the foreign country, and an example of the latter is the foreign tariff rate.

With a few notable exceptions (see, for example, Grubert and Mutti 1991a; Cummins and Hubbard 1995; Brainard 1995; Cooke and Noble 1998), it is difficult to find examples in the literature on MNC production location decisions and FDI in which authors have estimated valid reduced forms in the sense that the explanatory variables include only quantities that are assumed exogenous in standard theoretical models of MNC behavior.

We turn next to a discussion of the dependent variables of interest. The most obvious measure of FDI in a particular host country is the capital of U.S. MNCs' affiliates in that country ( $K$ in our notation). Of course, there are well-known problems with measuring capital stocks. We proxy for affiliates' capital stock using the assets of majority-owned foreign affiliates (MOFAs) in a particular country, as reported by the 
Bureau of Economic Analysis (BEA). ${ }^{6}$ We then model the share of U.S. MNCs' worldwide capital stock (within each manufacturing industry) that is allocated to each of 22 potential host countries.

Working with shares has several virtues. First, it enables us to avoid modeling the determinants of the overall level of the MNC capital stock. This would obviously require a dynamic model of investment behavior, raising a host of serious complications that are tangential to our main focus. Instead, we focus on how the relative attractiveness of potential host countries (as determined by the set of assumed exogenous variables described earlier) affects their share of MNCs' worldwide capital stock. ${ }^{7}$ Second, a related point is that working with shares alleviates some of the wellknown problems associated with finding an appropriate price index to measure growth of the real capital stock over time. Third, working with shares helps to alleviate heteroskedasticity problems that typically arise in a panel data context when one pools data from industries or countries (or both) that differ in size. We discuss this further below, under "Econometric Issues."

Of course, our focus is not just on U.S. MNCs' allocation of capital to various potential host countries, but also on MOFA

\footnotetext{
${ }^{6}$ In contrast, many existing studies look at balance of payments measures of FDI. As Stevens (1972) and Grubert and Mutti (1991b) pointed out, this is inappropriate for studying real investment decisionswhich is what we are interested in. The problem is that FDI financed by local borrowing in the host country does not affect the balance of payments. This point is not just academic. Grubert and Mutti found that the correlation over time between the U.S. balance of payments measure of FDI in Canada and the fixed investment expenditures of U.S. MNC affiliates in Canada is essentially zero. And Culem (1988) found that FDI flows are driven by nominal interest rate differentials.

${ }^{7} \mathrm{By}$ analogy, in the consumption literature, it is common to model shares of household spending allocated to each category of goods, as a function of relative prices of those goods, in a static framework. This avoids the complex task of modeling the overall level of consumption, which would require dynamic modeling of saving behavior.
}

employment ( $L_{f}$ in our notation). Also, following earlier literature, we examine another measure of the size of MNCs' foreign operations: the sales of U.S. MOFAs in each host country, net of their imports from the U.S. parent. Again, we look at specifications in which the dependent variables are specified as the shares of U.S. MNCs' worldwide employment or net sales located in each host country.

We hasten to point out a key problem with the net sales measure: since sales equals price times quantity, one cannot interpret the coefficients on covariates in a net sales regression as necessarily capturing effects on scale of MNC operations. Rather, the coefficients will capture the effects of covariates on both the volume of production and the price level. To the extent that the MNC has market power in the host country (and theories of the MNC imply that it should), a drop in local production may lead to a higher price. Still, since it has been common in FDI literature to use net sales as a measure of the size of MNCs' local operations in each host country, we look at this dependent variable for the sake of comparability with earlier studies.

We conclude this section with a specific discussion of some earlier studies that focused on the role of wages and IR factors in MNC production location decisions. Karier (1995) estimated equations for value added, sales, and employment of foreign affiliates of U.S. MNCs in 32 industries and 10 geographic regions, using data from the BEA's 1982 benchmark survey. He found that unionization rates in host countries were statistically insignificant in the value added and sales equations, and actually were positive and statistically significant in the employment equation. However, he included capital-labor ratios, $\mathrm{R} \& \mathrm{D}$, and advertising expenditures as explanatory variables, all of which we would argue are endogenous, and this clouds the interpretation of the results. He did not control for wage rates or unobserved country/industry effects (since he used data for only one year).

Cooke (1997) examined data from the 1989 BEA survey. He looked at assets of 
U.S. MNC foreign affiliates in nine industries and nineteen industrialized host countries, and considered four IR factors: the unionization rate, decentralized bargaining, layoff restrictions, and whether works councils were required. His results were mixed: centralized bargaining, hiring/firing restrictions, and higher unionization rates were all associated with lower assets in 1989 (as expected), while work council requirements were associated with higher assets (which is unexpected). When Cooke and Noble (1998) extended this analysis to a sample that included developing countries and also looked at employment, they obtained similar results. However, since these papers used only one year of data, they could not control for country/industry effects. Cooke found that wage rates were statistically insignificant, even though he used average education levels of countries to control for worker quality. And Cooke and Noble found the typical positive coefficient on wages in both asset and employment equations (provided wages were above a certain threshold level). ${ }^{8}$

As indicated in the introduction, one plausible reason for obtaining the "wrong" sign on wages in MOFA employment equations is failure to control adequately for intrinsic differences in worker productivity across countries. Some authors try to address this problem by using unit labor costs rather than wage rates as measures of labor costs (see, for example, Devereux and Griffith 1996, or Erickson and Kuruvilla 1994). But this is problematic, because unit labor costs are themselves endogenous. They depend in general on the production technology of firms and their factor input

\footnotetext{
${ }^{8}$ More recently, Cooke (2001) examined the allocation of FDI by MNCs of each of 16 OECD countries among the other 15 OECD countries, using OECD data from 1994. He found that centralized bargaining and layoff restrictions discourage FDI. He attempted to control for worker quality differences using the average education level in each country. But he still obtained an unexpected positive coefficient on the wage per year of education.
}

decisions. ${ }^{9}$ We argue that a better way to deal with the problem is to use panel data techniques to control for country-specific unobservables that drive productivity differences.

\section{Data}

Our data on assets, employment, and net sales of U.S.-based MNCs and their majority-owned foreign affiliates (MOFAs) come from the Annual and Benchmark Surveys of U.S. Direct Investment Abroad, administered by the Bureau of Economic Analysis (BEA). These are the most comprehensive available data on the activities of U.S.-based MNCs and their foreign affiliates.

We use the BEA data on 7 manufacturing industries and 22 countries for the years 1982-91. The industries are food and kindred products, chemicals and allied products, primary and fabricated metals, machinery and nonelectronic equipment, electronic equipment, transportation, and "other." The 22 countries include 15 European countries, Japan, Australia, New Zealand, Singapore, Korea, Mexico, and Canada. We chose these countries because we were able to obtain complete data for them on the IR and other control variables of interest. The BEA reports data on assets and sales in U.S. dollars, based on average spot exchange rates for the fiscal year.

Given our 10-year sample period, and the fact that we use 7 industries and 22 countries, there are 1,540 total potential observations on each dependent variable. But the BEA suppresses data in cases where the information might reveal the activities of particular firms (in particular, if only one or two U.S. MNCs have an affiliate in a particular industry located in a particular country). Thus, the data actually contain 1,202 total observations on assets, 1,273 on

${ }^{9}$ For example, given a Cobb-Douglas technology $y$ $=K^{\alpha}(\beta L)^{1-\alpha}$, where $\beta$ is efficiency units per unit of labor, the firm sets $w L / y=(1-\alpha)$. Thus, the unit labor cost is $(1-\alpha)$, regardless of the wage per efficiency unit $(w / \beta)$. 
employment, and 941 on net sales. We also drop cells with zero values, leaving 1,150 , 1,218 , and 881 observations, respectively.

For manufacturing industries, the 22 countries in our sample account for over $80 \%$ of all U.S. MOFA sales and $70-76 \%$ of all U.S. MOFA employment for this period. Furthermore, the sample countries closely parallel the time-series pattern of worldwide sales and employment of all U.S. MOFAs in manufacturing industries. ${ }^{10}$ Thus, we doubt that including other (smaller) countries as potential targets of FDI would have much effect on our results.

We model the production location decisions of U.S. MNCs as depending on a set of independent variables that capture the attractiveness of both the United States and the set of foreign host countries as production locations. These independent variables include U.S. and host country average manufacturing wage rates, corporate tax rates, and tariff rates. Proxies for U.S. and host country market size and relative demand, as well as transportation costs, are also included, along with miscellaneous macroeconomic variables meant to capture time effects on costs of capital or demand. Finally, we include a set of variables that capture features of the IR environment in the United States and each host country. We next describe each of these variables.

Data on foreign and U.S. hourly manufacturing wages are obtained from the U.S. Department of Labor (1993), and they are converted into U.S. dollar values using nominal exchange rates. They are then put on a 1985 base using the U.S. GDP deflator (the same is true of all nominal variables described below). To conserve on parameters, we enter the wage rates in ratio form, as the ratio of the foreign wage to the U.S. wage.

Average corporate tax rates for the 22

\footnotetext{
${ }^{10}$ It is worth noting that MOFA total assets (in manufacturing industries) grew rapidly from $\$ 213$ billion in 1982 to $\$ 369$ billion in 1991. But total employment showed no trend (that is, it fluctuated in the 3.0-3.4 million range).
}

foreign countries are constructed from the BEA data, by calculating the percentage of total affiliate income paid in taxes by country and by year. We obtained U.S. corporate income tax rates from Cummins, Harris, and Hassett (1995). Differences between foreign tax rates and the U.S. tax rate are then included in the model.

U.S. and foreign tariff rates are taken from the International Data Base compiled by the World Trade Organization (WTO). The ad valorem nominal tariff rates compiled by the WTO are industry average rates, unweighted by imports. Since the BEA uses a system of ISI industry codes based on 2- to 3-digit U.S. SIC codes, we converted the 3-digit SITC codes used in the WTO tariff data into 3-digit SIC codes, and subsequently in to the BEA's ISI codes. ${ }^{11}$

Tariff rates are Most Favored Nation duties because all 22 of the sample countries are members of GATT (the General Agreement on Trade and Tariffs). Participants in the Tokyo round of the GATT agreed to implement an average one-third tariff reduction in eight equal annual increments beginning January 1, 1980 (see Kowalczyk and David 1998). Thus, tariff rates set by the Tokyo Round apply to the first six years of our data set, 1982-87. There were no further major multilateral negotiations until the Uruguay round, which specified additional tariff reductions beginning in 1995. Thus, we use the initial tariff levels from the Uruguay round to measure tariffs in the years 1988-91. An exception is made in the case of Canada, since the U.S.-Canada Free Trade Agreement (FTA) went into effect in 1989. Thus, rates specified by the FTA were used after 1989. We include both current and fiveyear leads of the U.S. and host country tariff rates in our models, to account for the

\footnotetext{
${ }^{11}$ To do this we use a concordance table published by the U.S. Department of Commerce (1995) in U.S. Exports and Imports of Merchandise (CD-ROM). Tariff rates for Mexico were not classified by U.N. SITC codes but rather by Harmonized System codes, so the concordance was made between Harmonized System and BEA industry codes.
} 
possibility that current MNC decisions depend on both current and anticipated future tariffs.

Foreign and U.S. real GDP are used to measure market size, which the "horizontal" model of MNCs suggests should be a key determinant of FDI. To capture relative market size, we enter these variables in ratio form (host country GDP divided by U.S. GDP). We also include the per capita income ratio (host country PCI divided by U.S. PCI). This is meant to capture the composition of demand (that is, the rise in the demand for manufactured goods as per capita income rises), but it should also help capture cross-country differences in worker productivity.

The earnings-to-price (EP) ratio for each national stock market is obtained from data sets compiled by Morgan Stanley Capital International and International Finance Corporation. We include these EP ratios as (arguably exogenous) determinants of the cost of raising equity capital in each country, and enter the foreign-U.S. difference in the model. ${ }^{12}$

The GDP, PCI, and EP ratio variables can all be viewed more generally as a set of controls for time-varying macroeconomic factors that influence MNC location decisions. We include an overall time trend as well, to capture omitted macroeconomic factors that may be altering the share of MNC assets, employment, and net sales that occur abroad.

The geographic distance between the United States and a host country is included to capture transportation costs. A dummy variable indicating whether a coun-

\footnotetext{
${ }^{12}$ We do not attempt to include firm- (or industry-) specific measures of the cost of capital because these may be endogenous. We assume that firm-specific activities do not affect the return on equity at the national level. We abstract from the problem that the overall level of FDI directed toward a country might affect the price of capital in that country (or factor prices more generally). To deal with this sort of endogeneity problem would require a worldwide general equilibrium framework, taking us well beyond the scope of our analysis.
}

try is a member of the European Community (EC) is also included, in recognition of the fact that locating a production facility inside Europe enables a U.S. MNC to jump the EC tariff wall, and also that location of production in Europe may be relatively easy due to cultural similarities.

We also include a "cultural openness" variable, which measures the extent to which a country is culturally varied and open to foreign influence, and a "corruption" variable that measures the extent to which improper practices such as bribery prevail in the public sphere. These are both taken from the World Competitiveness Report $(1992,1990)$.

We characterize the IR environment of each host country by five variables: union density, strike intensity, collective bargaining structure, works councils, and layoff restrictions. Union density is meant to capture the likelihood that an affiliate located in a particular host country will be unionized. To the extent that U.S. MNCs would prefer to operate non-union, they will tend to locate production in countries with relatively low union densities. Union densities for the OECD countries are taken from Visser (1991). For Singapore, Korea, and Mexico, we refer to government reports and Foreign Labor Trends (U.S. Department of Labor). Since data on union densities for all sample countries are only available for 1982, 1985, and 1988, the union densities in those years are carried forward for 1983-84, 1986-87, and 1989-91, respectively.

The strike intensity variable is meant to capture the potential cost of unionization in terms of lost production. It is measured by the number of working days lost to strikes per employee. For OECD countries, we use U.K. Department of Labor statistics on strike intensity reported in Employment Gazette. For non-OECD countries, the ILO's Yearbook of Labor Statistics or government publications of the particular countries are used.

The collective bargaining variable measures the extent to which bargaining is centralized (that is, largely conducted at the national, regional, industrial, or occupational level) versus decentralized (largely 
Table 1. Variable Definitions and Sources.

\begin{tabular}{|c|c|}
\hline Variable & Definition and Source \\
\hline MOFA total asset ratio & $\begin{array}{l}\text { U.S. majority-owned foreign affiliates' total assets in industry } i \text {, } \\
\text { country } j \text {, year } t \text {, divided by U.S. MNCs' worldwide total assets in } \\
\text { industry } i \text {, year } t \text {. Source: U.S. Department of Commerce (1985-94). }\end{array}$ \\
\hline MOFA total employment ratio & $\begin{array}{l}\text { U.S. majority-owned foreign affiliates' total employment in industry } i \text {, } \\
\text { country } j \text {, year } t \text {, divided by U.S. MNCs' worldwide total employment } \\
\text { in industry } i \text {, year } t \text {. Total employment is the sum of full-time and } \\
\text { part-time workers. Source: U.S. Department of Commerce (1985-94). }\end{array}$ \\
\hline MOFA net sale ratio & $\begin{array}{l}\text { U.S. majority-owned foreign affiliates' net sales in industry } i \text {, country } \\
j \text {, year } t \text {, divided by U.S. MNCs' worldwide net sales in industry } i \text {, year } \\
t \text {. Net sales is total sales minus MOFA imports from the United States } \\
\text { and other countries. Source: U.S. Department of Commerce (1985- } \\
94) \text {. }\end{array}$ \\
\hline
\end{tabular}

Wage ratio

Ratio of the hourly compensation rate of manufacturing production workers in host country $j$ at time $t$ to that in the United States at time $t$. Compensation is the sum of base pay and fringe benefits per hour. Source: U.S. Department of Labor (1993).

Union density

Proportion of wage and salary workers in country $j$ in year $t$ who are employed union members. Source: Visser (1991) and various government reports of Asian countries.

Strike intensity

Days lost per worker due to work stoppages in country $j$ in year $t$. Sources: U.K. Department of Labor (1992) and ILO (1995).

Collective bargaining structure

Degree of decentralization in bargaining structure. Sources: Calmfors and Driffill (1988) and the authors' own calculations.

Works councils

Layoff restrictions

Equals 1 if works councils are legally recognized or prevail in the host country; equals 0 otherwise. Source: Kleiner and Ay (1996).

Equals 1 if country requires employers to notify government labor office and consult with unions or works councils about layoffs; equals 0 otherwise. Sources: Cooke and Noble (1998) and authors' own calculations.

GDP ratio

The ratio of host country GDP to U.S. GDP. Sources: OECD, National Account-Main Aggregates (various years) and IMF, International Financial Statistics Yearbook (various years).

Geographic distance

Direct land and sea distance between capitals of the U.S. and foreign countries. Source: Fitzpatrick and Modlin (1986).

conducted at the firm or plant level). We expect U.S. MNCs to prefer one-on-one negotiations with individual unions, rather than a multi-employer framework. We measure centralization using an adaptation of the Calmfors and Driffill (1988) index, which is available for 16 of our 22 countries. The index is on a scale of 0 to 6 , with 0 indicating the maximum degree of centralization. Calmfors and Driffill did not classify Korea, Mexico, Greece, Portugal, Singapore, and Spain, so we applied the same criteria to classify them, using descriptions given in Rothman, Briscoe, and Nacamulli (1993), Commission of the European Communities (1994), and Torriente (1997). Our classifications are reported in Appendix Table A1.

Finally, the Works Council dummy variable is set equal to one if works councils are legally recognized or prevail in the country, as reported in Kleiner and Ay (1996), and the Layoff Restriction dummy equals one if the country requires employers to notify the government and consult with unions or works councils about layoffs, as reported by Cooke and Noble (1998). We have rated countries that were not included 
Table 1. Continued.

\begin{tabular}{|c|c|}
\hline Variable & Definition and Source \\
\hline English dummy & $\begin{array}{l}\text { Equals } 1 \text { if the country uses English as a native language; equals } 0 \\
\text { otherwise. Australia, Canada, Ireland, New Zealand, and the United } \\
\text { Kingdom are coded as } 1 \text {. }\end{array}$ \\
\hline PCI ratio & $\begin{array}{l}\text { Ratio of host country per capita income to U.S. per capita income. } \\
\text { Source: United Nations Conference on Trade and Development } \\
(1982-93) \text {. }\end{array}$ \\
\hline EC membership & $\begin{array}{l}\text { Equals } 1 \text { if the country is a member of the European Community; } \\
\text { equals } 0 \text { otherwise. The European countries that were EC members } \\
\text { are Belgium, Denmark, France, Germany, Greece, Ireland, Italy, the } \\
\text { Netherlands, Portugal, Spain, and the United Kingdom. The } \\
\text { European countries that were not EC members (during our sample } \\
\text { period) are Austria, Norway, Sweden, and Switzerland. }\end{array}$ \\
\hline $\begin{array}{l}\text { Corporate income tax rate } \\
\text { difference }\end{array}$ & $\begin{array}{l}\text { The host country corporate income tax rate in year } t \text { minus the U.S. } \\
\text { corporate income tax rate in year } t \text {. Sources: The percentage of total } \\
\text { affiliate net income paid as income taxes in country } j \text { in year } t \text { was } \\
\text { calculated from BEA annual and benchmark surveys. For the U.S. tax } \\
\text { rates, see Cummins, Harris, and Hassett (1995). }\end{array}$ \\
\hline Earnings-to-price ratio difference & $\begin{array}{l}\text { Difference between foreign and U.S. earnings-to-price ratio, for stock } \\
\text { market in host country } j \text { in year } t \text {. Monthly ratios were averaged to } \\
\text { yearly ratios. Source: unpublished data from Morgan Stanley Capital } \\
\text { International and International Finance Corporation. }\end{array}$ \\
\hline Cultural openness & $\begin{array}{l}\text { The extent to which the culture of a host country is open to foreign } \\
\text { influence. Source: IMD (1992). }\end{array}$ \\
\hline Corruption & $\begin{array}{l}\text { The extent to which improper practices such as bribing prevail in the } \\
\text { public sphere. Source: IMD (1990). }\end{array}$ \\
\hline Foreign tariff rate & $\begin{array}{l}\text { Ad valorem tariff rates in industry } i \text {, country } j \text {, and year } t \text {. } \\
\text { Source: WTO (1995). }\end{array}$ \\
\hline U.S. tariff rate & $\begin{array}{l}\text { Ad valorem tariff rates in industry } i \text { and year } t \text {. Between U.S. and } \\
\text { Canada, FTA tariff rates were used after the year 1989. Source: WTO } \\
\text { (1995). }\end{array}$ \\
\hline Time trend & Ranges from 1 to 10 for the period $1982-91$. \\
\hline
\end{tabular}

in Cooke and Noble's study (see Appendix Table A1).

Table 1 contains a complete list of variable definitions, and descriptive statistics are given in Table 2. Appendix Table A1 gives the IR environment variables for each country in our sample.

Table 3 presents the fraction of MOFA assets and employment in each of the 22 sample countries in 1982 versus 1991. The striking impression conveyed by this table is that the relative size of U.S. MNCs' operations in the various countries is very stable over the sample period. For instance, for the share of MNC employment located in each host country, the top 8 ranked countries are identical in 1982 and 1991, and the top 3 are all industrialized countries (the United Kingdom, Canada, and Germany). Thus, there is no overall pattern of movement of MNC activities toward low-wage countries during this period. The one obvious exception is Mexico: the share of U.S. MNCs' worldwide employment located in Mexico increased from $1.67 \%$ in 1982 to $2.86 \%$ in 1991 , a substantial increase. Nevertheless, Mexico's employment rank stays fixed at 4 .

Note, however, that the failure to see MNC activities moving into low-wage countries over time has no bearing on the extent to which MNCs prefer to locate in low-wage countries. As Grubert and Mutti (1991a) pointed out in a different context, results 
Table 2. Descriptive Statistics.

\begin{tabular}{lcc}
\hline Variable & Mean & Standard Deviation \\
\hline Dependent Variables: & & 1.20 \\
MOFA total asset ratio & 0.94 & 1.55 \\
MOFA total employment ratio & 1.21 & 1.68 \\
MOFA net sales ratio & 1.43 & 0.35 \\
Independent Variables: & & 18.44 \\
Wage ratio (foreign/U.S.) & 0.72 & 0.74 \\
Foreign union density (\% union member) & 39.91 & 0.96 \\
Foreign strike intensity (days per worker) & 0.25 & 0.50 \\
Collective bargaining structure & 2.16 & 0.46 \\
Works council & 0.55 & 0.08 \\
Layoff restriction & 0.32 & 3.26 \\
GDP ratio (foreign/U.S.) & 0.07 & 0.44 \\
Geographic distance (in 1000s of km) & 6.57 & 0.30 \\
English language dummy & 0.26 & 0.50 \\
Per capita income (foreign/U.S.) & 0.67 & 0.17 \\
European Community membership & 0.52 & 0.03 \\
Corporate tax rate difference & -0.05 & 10.95 \\
Earnings-to-price ratio difference & -0.008 & 9.07 \\
Cultural openness (1992) & 60.49 & 15.42 \\
Corruption (1990) & 61.93 & 1.18 \\
Foreign nominal tariff rate & 10.82 & 2.87 \\
U.S. nominal tariff rate & 4.19 & 5.64 \\
Time trend & & \\
\hline
\end{tabular}

for changes in assets and employment are difficult to interpret because, in equilibrium, one would not see any association between levels of exogenous variables and changes in endogenous variables. For example, if relative wages across countries were fairly stable during the sample period, then lack of movement is consistent with a scenario in which relative wages are a very important determinant of MNG location decisions, provided that the equilibrium allocation of MNC activities across countries in 1981 already reflected this factor. This highlights why a multivariate analysis that exploits both cross-sectional and temporal co-variation in FDI and its determinants is essential in order to shed further light on the determinants of MNC production location decisions.

\section{Econometric Issues}

An important problem in panel data studies in which data for different countries, industries, or both are combined is the potential for heteroskedasticity. This problem often arises because of intrinsic differences in size between the different countries or industries. The variance of the error terms (over time) tends to be much greater for the larger industries or countries. We found that heteroskedasticity was indeed a severe problem in our data.

Typical methods for dealing with heteroskedasticity often involve transformations that "rein in" large values of the dependent variable (thus reducing skewness). Common examples are normalizing by some measure of size, or taking logs. In our analysis, we normalize the dependent variables by converting them to shares. For instance, for employment, the total MOFA employment of each industry in each host country is divided by the worldwide employment of U.S. MNCs in that industry. Similar normalizations are done for MOFA assets and net sales.

Conversion to shares substantially reduced the heteroskedasticity in our data, but fell far short of eliminating it. That is, 
Table 3. Shares of U.S. MNC Assets and Employment Located in Each Host Country.

\begin{tabular}{|c|c|c|c|c|c|c|c|c|}
\hline \multirow[b]{2}{*}{ Host Country } & \multicolumn{4}{|c|}{ MOFAs' Share of Worldwide Assets } & \multicolumn{4}{|c|}{ MOFAs' Share of Worldwide Employment } \\
\hline & 1982 & Rank & 1991 & Rank & 1982 & Rank & 1991 & Rank \\
\hline Canada & 2.76 & 1 & 2.79 & 2 & 3.34 & 2 & 3.14 & 2 \\
\hline United Kingdom & 2.58 & 2 & 2.97 & 1 & 3.79 & 1 & 3.48 & 1 \\
\hline Germany & 1.92 & 3 & 2.77 & 3 & 2.97 & 3 & 3.08 & 3 \\
\hline France & 0.96 & 4 & 1.49 & 4 & 1.53 & 5 & 1.57 & 5 \\
\hline Italy & 0.64 & 5 & 1.03 & 5 & 0.96 & 6 & 0.90 & 6 \\
\hline Netherlands & 0.60 & 6 & 0.96 & 6 & 0.51 & 10 & 0.62 & 10 \\
\hline Mexico & 0.52 & 7 & 0.42 & 11 & 1.67 & 4 & 2.86 & 4 \\
\hline Australia & 0.45 & 8 & 0.57 & 8 & 0.67 & 8 & 0.73 & 8 \\
\hline Japan & 0.39 & 9 & 0.39 & 12 & 0.35 & 11 & 0.64 & 9 \\
\hline Belgium & 0.36 & 10 & 0.47 & 9 & 0.64 & 9 & 0.34 & 12 \\
\hline Spain & 0.25 & 11 & 0.70 & 7 & 0.68 & 7 & 0.74 & 7 \\
\hline Ireland & 0.20 & 12 & 0.42 & 10 & 0.23 & 13 & 0.30 & 13 \\
\hline Singapore & 0.17 & 13 & 0.27 & 13 & 0.23 & 12 & 0.52 & 11 \\
\hline Sweden & 0.08 & 14 & 0.06 & 15 & 0.09 & 15 & 0.13 & 15 \\
\hline Switzerland & 0.06 & 15 & 0.05 & 17 & 0.11 & 14 & 0.04 & 18 \\
\hline Denmark & 0.06 & 16 & 0.03 & 19 & 0.06 & 19 & 0.05 & 17 \\
\hline Austria & 0.04 & 17 & 0.03 & 18 & 0.08 & 17 & 0.04 & 19 \\
\hline Greece & 0.03 & 18 & 0.02 & 20 & 0.03 & 21 & 0.04 & 20 \\
\hline Portugal & 0.02 & 19 & 0.05 & 16 & 0.08 & 18 & 0.07 & 16 \\
\hline New Zealand & 0.01 & 20 & 0.02 & 21 & 0.05 & 20 & 0.04 & 21 \\
\hline Korea & 0.01 & 21 & 0.08 & 14 & 0.09 & 16 & 0.15 & 14 \\
\hline Norway & 0.004 & 22 & 0.003 & 22 & 0.01 & 22 & 0.02 & 22 \\
\hline
\end{tabular}

Note: The MOFA share of worldwide assets is the ratio of MOFA total assets in a host country to U.S. MNCs' worldwide total assets (that is, parent plus MOFA assets). Employment share is defined similarly. The Bureau of Economic Analysis denominates MOFAs' assets and U.S. worldwide assets in U.S. dollars using annual average exchange rates.

industry/country cells with relatively large shares tend to have greater variability in their shares over time. A log transformation resulted in an over-correction: industry/country cells with smaller shares tend to have greater variability in their $\log$ shares over time. Hence, we used a Box-Cox transformation (intermediate between the $\log$ and linear cases) to effect the degree of skewness correction needed to eliminate heteroskedasticity.

Thus, our estimating equations are of the form

$$
\left(Y_{i c t}^{\lambda}-1\right) / \lambda=X_{i c t} \beta+\phi_{i c}+\varepsilon_{i c t},
$$

where $Y_{i c t}$ is the dependent variable (share of assets, employment, or net sales) for industry $i$ allocated to host country $c$ in year $t, \lambda$ is the Box-Cox parameter, $X_{i c t}$ is a vector of (assumed) exogenous influences on MNC behavior, $\phi_{i c}$ is an industry/country-specific effect, and $\varepsilon_{i c t}$ is an idiosyncratic

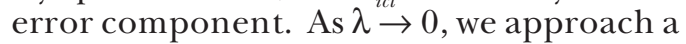
$\log$ transformation.

In the OLS specification, the $\phi_{i c}$ are ignored. The random effects (RE) model assumes that the $\phi_{i c}$ are present but that $E\left(\phi_{i c} \mid X_{i c 1}, \ldots, X_{i c T}\right)=0$ (that is, there is mean independence). The fixed effects (FE) model does not restrict the distribution of the $\phi_{i c}$ in this way. If the RE assumption holds, the RE effects estimator is consistent and efficient. ${ }^{13}$ The OLS estimator is also

\footnotetext{
${ }^{13}$ Consistency of the RE estimator actually requires the additional assumption of strict exogeneity, $E\left(\varepsilon_{i c t} X_{i c s}\right)=0$ for all $t, s$. The same is true of the FE estimator. Consistency of pooled OLS does not require this assumption.
} 
Table 4. Majority-Owned Foreign Affiliates' Total Asset Ratio.

\begin{tabular}{|c|c|c|c|c|c|c|c|}
\hline Variable & $O L S$ & $\begin{array}{l}\text { Random } \\
\text { Effect }\end{array}$ & $\begin{array}{l}\text { Fixed } \\
\text { Effect }\end{array}$ & Variable & $O L S$ & $\begin{array}{l}\text { Random } \\
\text { Effect }\end{array}$ & $\begin{array}{l}\text { Fixed } \\
\text { Effect }\end{array}$ \\
\hline $\begin{array}{l}\text { Wage Ratio } \\
\text { (Foreign/U.S.) }\end{array}$ & $\begin{array}{l}1.974 * * \\
(0.243)^{\mathrm{a}}\end{array}$ & $\begin{array}{c}0.232 \\
(0.120)\end{array}$ & $\begin{array}{c}0.164 \\
(0.126)\end{array}$ & $\begin{array}{l}\text { Control Variables (continued): } \\
\text { Cultural Openness }\end{array}$ & $\begin{array}{l}0.028 * * \\
(0.004)\end{array}$ & $\begin{array}{l}0.047 * * \\
(0.007)\end{array}$ & - \\
\hline $\begin{array}{l}\text { Foreign Union } \\
\text { Density }\end{array}$ & $\begin{array}{l}-0.0029 \\
(0.0025)\end{array}$ & $\begin{array}{l}-0.0025 \\
(0.0024)\end{array}$ & $\begin{array}{l}-0.0021 \\
(0.0027)\end{array}$ & Corruption & $\begin{array}{l}-0.007 \\
(0.005)\end{array}$ & $\begin{array}{c}-0.023^{*} \\
(0.011)\end{array}$ & - \\
\hline $\begin{array}{l}\text { Foreign Strike } \\
\text { Intensity }\end{array}$ & $\begin{array}{l}-0.085^{* *} \\
(0.031)\end{array}$ & $\begin{array}{c}0.006 \\
(0.018)\end{array}$ & $\begin{array}{c}0.006 \\
(0.019)\end{array}$ & $\begin{array}{l}\text { Foreign Nominal } \\
\text { Tariff }\end{array}$ & $\begin{array}{c}0.006 \\
(0.017)\end{array}$ & $\begin{array}{l}0.032 * * \\
(0.007)\end{array}$ & $\begin{array}{l}0.029 * * \\
(0.008)\end{array}$ \\
\hline $\begin{array}{l}\text { Collective Bargaining } \\
\text { Structure }\end{array}$ & $\begin{array}{l}0.117 * * \\
(0.042)\end{array}$ & $\begin{array}{c}0.155 \\
(0.086)\end{array}$ & - & $\begin{array}{l}\text { Foreign Nominal } \\
\text { Tariff }(+5)\end{array}$ & $\begin{array}{c}-0.010 \\
(0.018)\end{array}$ & $\begin{array}{l}-0.032 * * \\
(0.008)\end{array}$ & $\begin{array}{c}-0.059 * * \\
(0.012)\end{array}$ \\
\hline $\begin{array}{l}\text { Works Council } \\
\text { Dummy }\end{array}$ & $\begin{array}{l}-0.569 * * \\
(0.146)\end{array}$ & $\begin{array}{l}-0.042 \\
(0.234)\end{array}$ & - & U.S. Nominal Tariff & $\begin{array}{c}-0.030 \\
(0.079)\end{array}$ & $\begin{array}{r}0.077 * \\
(0.037)\end{array}$ & $\begin{array}{l}0.101^{* *} \\
(0.038)\end{array}$ \\
\hline $\begin{array}{l}\text { Layoff Restriction } \\
\text { Dummy }\end{array}$ & $\begin{array}{c}-0.073 \\
(0.120)\end{array}$ & $\begin{array}{l}-0.256 \\
(0.234)\end{array}$ & - & $\begin{array}{l}\text { U.S. Nominal } \\
\text { Tariff }(+5)\end{array}$ & $\begin{array}{l}0.372 * * \\
(0.073)\end{array}$ & $\begin{array}{c}0.048 \\
(0.032)\end{array}$ & $\begin{array}{c}0.017 \\
(0.034)\end{array}$ \\
\hline F-Test for IR Variables: & & & & Time Trend & $\begin{array}{l}0.046^{* *} \\
(0.012)\end{array}$ & $\begin{array}{l}0.048 * * \\
(0.008)\end{array}$ & $\begin{array}{l}0.037 * * \\
(0.009)\end{array}$ \\
\hline F-Statistics (p-value $)^{b}$ & $\begin{array}{l}13.16^{* *} \\
(0.000)\end{array}$ & $\begin{array}{l}7.69 * * \\
(0.000)\end{array}$ & $\begin{array}{l}0.33 \\
(0.718)\end{array}$ & $\begin{array}{l}\text { Industry Dummy } 1 \\
(\text { Food })^{c}\end{array}$ & $\begin{array}{l}0.749 * * \\
(0.123)\end{array}$ & $\begin{array}{c}0.382 \\
(0.211)\end{array}$ & - \\
\hline $\begin{array}{l}\text { Control Variables: } \\
\text { GDP Ratio }\end{array}$ & $38.214 * *$ & $28.711^{* *}$ & -5.193 & $\begin{array}{l}\text { Industry Dummy } 2 \\
\text { (Chemical) }\end{array}$ & $\begin{array}{l}1.215^{* *} \\
(0.163)\end{array}$ & $\begin{array}{l}0.730 * * \\
(0.217)\end{array}$ & - \\
\hline $\begin{array}{c}\text { (Foreign/U.S.) } \\
\text { Geographic Distance }\end{array}$ & $\begin{array}{l}(2.382) \\
0.111 * *\end{array}$ & $\begin{array}{c}(4.151) \\
0.053\end{array}$ & $\begin{array}{c}(10.307) \\
-\end{array}$ & $\begin{array}{l}\text { Industry Dummy } 3 \\
\text { (Metals) }\end{array}$ & $\begin{array}{l}0.724 * * \\
(0.188)\end{array}$ & $\begin{array}{c}0.098 \\
(0.227)\end{array}$ & - \\
\hline GDP Ratio $\times$ Distance & $\begin{array}{l}(0.014) \\
-3.685^{* *}\end{array}$ & $\begin{array}{l}(0.029) \\
-2.414^{* *}\end{array}$ & 1.715 & $\begin{array}{l}\text { Industry Dummy } 4 \\
\text { (Equip.) }\end{array}$ & $\begin{array}{l}1.229 * * \\
(0.147)\end{array}$ & $\begin{array}{l}0.625 * * \\
(0.215)\end{array}$ & - \\
\hline English Dummy & $\begin{array}{l}(0.279) \\
-0.504\end{array}$ & $\begin{array}{c}(0.513) \\
0.461\end{array}$ & $\begin{array}{c}(1.250) \\
-\end{array}$ & $\begin{array}{l}\text { Industry Dummy } 5 \\
\text { (Elect.) }\end{array}$ & $\begin{array}{r}0.207 * \\
(0.095)\end{array}$ & $\begin{array}{l}-0.016 \\
(0.203)\end{array}$ & - \\
\hline GDP Ratio $\times$ English & $\begin{array}{l}(0.279) \\
5.590 * *\end{array}$ & $\begin{array}{c}(0.256) \\
6.354\end{array}$ & 2.898 & $\begin{array}{l}\text { Industry Dummy } 6 \\
\text { (Transport) }\end{array}$ & $\begin{array}{l}0.162 \\
(0.165)\end{array}$ & $\begin{array}{c}-0.239 \\
(0.226)\end{array}$ & - \\
\hline PCI Ratio & $\begin{array}{l}(1.322) \\
-2.148 * *\end{array}$ & $\begin{array}{l}(3.286) \\
-0.093\end{array}$ & $\begin{array}{c}(16.168) \\
0.050\end{array}$ & Constant & $\begin{array}{l}-5.978 * * \\
(0.629)\end{array}$ & $\begin{array}{l}-5.421 * * \\
(0.883)\end{array}$ & - \\
\hline (Foreign/U.S.) & $(0.258)$ & $(0.139)$ & $(0.152)$ & No. of Observations & 1,150 & 1,150 & 1,150 \\
\hline EC Dummy & $\begin{array}{l}0.345^{*} \\
(0.161)\end{array}$ & $\begin{array}{c}0.341 \\
(0.183)\end{array}$ & - & Box-Cox Lambda & 0.2 & $\begin{array}{l}0.2 \\
0.09\end{array}$ & $\begin{array}{l}0.2 \\
0.14\end{array}$ \\
\hline PCI Ratio $\times$ EC & $\begin{array}{c}0.255 \\
(0.203)\end{array}$ & $\begin{array}{l}0.524 * * \\
(0.121)\end{array}$ & $\begin{array}{l}0.626 * * \\
(0.129)\end{array}$ & Hausman Test (critical & $(0.412)$ & $(0.763)$ & $(0.708)$ \\
\hline PCI Ratio $\times$ English & $\begin{array}{c}0.830^{*} \\
(0.390)\end{array}$ & $\begin{array}{c}0.165 \\
(0.180)\end{array}$ & $\begin{array}{c}0.258 \\
(0.200)\end{array}$ & $\begin{array}{l}\text { F Test for Significance } \\
\text { of Fixed Effects ( } p \text {-value) }\end{array}$ & - & - & $\begin{array}{l}74.67 * * \\
62.37 * * \\
(0.000)\end{array}$ \\
\hline $\begin{array}{l}\text { Tax Rate } \\
\text { Difference } \\
\text { (Foreign - U.S.) }\end{array}$ & $\begin{array}{l}-0.060 \\
(0.186)\end{array}$ & $\begin{array}{l}-0.093 \\
(0.081)\end{array}$ & $\begin{array}{l}-0.163 \\
(0.086)\end{array}$ & R-Square & 0.78 & 0.75 & 0.98 \\
\hline $\begin{array}{l}\text { Earnings-to-Price Ratio } \\
\text { Difference } \\
\text { (Foreign - U.S.) }\end{array}$ & $\begin{array}{l}4.041 * * \\
(0.782)\end{array}$ & $\begin{array}{c}0.619 \\
(0.339)\end{array}$ & $\begin{array}{c}0.193 \\
(0.348)\end{array}$ & & & & \\
\hline
\end{tabular}

${ }^{\text {a}}$ Figures in parentheses are standard errors.

${ }^{\mathrm{b}}$ Critical values of the F-test are 2.21 for OLS and random effect models and 3.00 for the fixed effect model.

"Omitted industry is "other."

* Statistically significant at the .05 level; **at the .01 level.

consistent in this case, but it is inefficient and produces inconsistent standard errors. However, one can construct robust standard errors (which we do). On the other hand, if the $\phi_{i c}$ are correlated with the $X_{i c t}$, only the fixed effects estimator is consistent, and both OLS and RE are inconsistent.

In our case, we would like the RE assumption to hold, because if we must rely 
on the FE estimator, then the coefficient on any country characteristic that is constant over time is not identified-and this applies to three of our five IR environment variables. We can test whether the RE assumption holds using a Durbin-WuHausman (DWH) test (see Hausman 1978). While this test is often treated as definitive, it is important to recognize that it is actually only valid under a strong set of auxiliary assumptions that are tangential to the RE versus FE distinction. Thus, we will advocate a more pragmatic approach to choosing between the RE and FE specifications that also considers the a priori reasonableness of the estimates produced by each model. As a practical matter, in order to minimize the importance of the unobserved $\phi_{i c}$, we should control for as many observed (exogenous) country characteristics as possible.

The Box-Cox parameter $\lambda$ was chosen in an effort to minimize heteroskedasticity in the error terms $\varepsilon_{i c t}$. We test for heteroskedasticity using the Breusch-Pagan LM test. It is useful to find a common value of $\lambda$ that eliminates heteroskedasticity in the OLS, $\mathrm{RE}$, and FE models, because only then are the magnitudes of the coefficient estimates comparable across models. ${ }^{14}$ We were in fact able to do this for assets, employment, and net sales (see Appendix Table A2).

\section{Empirical Results}

Our main estimation results, which use either the share of MOFA assets or employment (by industry) located in each host country as the dependent variable, are reported in Tables 4 and 5, respectively. Appendix Table A2 describes the grid search we used to settle on a Box-Cox parameter

\footnotetext{
${ }^{14}$ Also, the usual method for implementing the DWH test relies on the assumption that, under the null hypothesis that the RE assumption is valid, the RE estimator is efficient. This means we should chose $\lambda$ to eliminate heteroskedasticity under the RE specification in order to implement the test. The FE model must be estimated using exactly the same $\lambda$, since the choice of $\lambda$ affects the scale of the coefficients and the DWH test is based on a comparison of RE- and FE-estimated coefficients.
}

for each dependent variable. As the results in Appendix Table A2 show, homoskedasticity was overwhelmingly rejected (by the Breusch-Pagan LM test) for both linear and $\log$ specifications for all dependent variables. We settled on a Box-Cox parameter of 0.20 for MOFA assets and 0.45 for MOFA employment. These values eliminate any statistically significant heteroskedasticity.

In Tables 4 and 5 we first report OLS results, in which the data for all countries, industries, and time periods are simply pooled. The fit of the OLS regressions is quite good. The R-squared values are .78 in the asset share equation and .80 in the employment share equation. These Rsquared values are unusually high for crosscountry/cross-industry regressions of this general type. Thus, the covariates that we have included in our models appear to do a good job of explaining the allocation of U.S. MNC assets and employment across countries.

The OLS coefficient estimates are, for the most part, not surprising. Notably, they indicate that market size is a very important determinant of the share of MNC operations located in each host country (for example, the coefficient on the ratio of host country to U.S. GDP is 38.2 in the asset share equation, with a standard error of only 2.4). Table 6 presents a list of effect sizes implied by each of the estimates. Effect sizes measure the change (in standard deviations) of the dependent variable associated with a one standard deviation change in an independent variable. Hence, they provide measures of the influence of each independent variable that are adjusted both for the units in which the variable is measured and for the variability of that variable in the sample. ${ }^{15}$ The figures in Table 6

\footnotetext{
${ }^{15}$ In contrast, elasticities adjust for units but not for variability. Effect sizes, unlike elasticities, can be compared across independent variables to get a feel for the relative importance of each variable in generating the in-sample variation of the dependent variable. We have adjusted the effect size estimates so they measure effects on the dependent variable itself at the mean of the data, as opposed to the Box-Cox transform of the dependent variable.
} 
Table 5. Majority-Owned Foreign Affiliates' Total Employment Ratio.

\begin{tabular}{|c|c|c|c|c|c|c|c|}
\hline Variable & $O L S$ & $\begin{array}{l}\text { Random } \\
\text { Effect }\end{array}$ & $\begin{array}{l}\text { Fixed } \\
\text { Effect }\end{array}$ & Variable & $O L S$ & $\begin{array}{l}\text { Random } \\
\text { Effect }\end{array}$ & $\begin{array}{l}\text { Fixed } \\
\text { Effect }\end{array}$ \\
\hline Wage Ratio & $1.469 * *$ & $-0.363 * *$ & $-0.424 * *$ & \multicolumn{4}{|l|}{ Control Variables (continued): } \\
\hline (Foreign/U.S.) & $(0.192)^{\mathrm{a}}$ & $(0.108)$ & $(0.113)$ & Cultural Openness & $0.013 * *$ & $0.030 * *$ & - \\
\hline \multicolumn{4}{|l|}{ Industrial Relations Variables: } & & $(0.003)$ & $(0.006)$ & \\
\hline $\begin{array}{l}\text { Foreign Union } \\
\text { Density }\end{array}$ & $\begin{array}{l}-0.0038 \\
(0.0021)\end{array}$ & $\begin{array}{l}-0.0016 \\
(0.0021)\end{array}$ & $\begin{array}{l}-0.0013 \\
(0.0024)\end{array}$ & Corruption & $\begin{array}{c}-0.010^{*} \\
(0.004)\end{array}$ & $\begin{array}{c}-0.023^{*} \\
(0.010)\end{array}$ & - \\
\hline $\begin{array}{l}\text { Foreign Strike } \\
\text { Intensity }\end{array}$ & $\begin{array}{l}-0.083 * * \\
(0.021)\end{array}$ & $\begin{array}{c}0.004 \\
(0.013)\end{array}$ & $\begin{array}{c}0.005 \\
(0.013)\end{array}$ & $\begin{array}{l}\text { Foreign Nominal } \\
\text { Tariff }\end{array}$ & $\begin{array}{l}-0.014 \\
(0.015)\end{array}$ & $\begin{array}{c}-0.0003 \\
(0.007)\end{array}$ & $\begin{array}{l}-0.005 \\
(0.007)\end{array}$ \\
\hline $\begin{array}{l}\text { Collective Bargaining } \\
\text { Structure }\end{array}$ & $\begin{array}{c}0.070 \\
(0.036)\end{array}$ & $\begin{array}{c}0.140 * \\
(0.070)\end{array}$ & - & $\begin{array}{l}\text { Foreign Nominal } \\
\text { Tariff }(+5)\end{array}$ & $\begin{array}{c}0.018 \\
(0.016)\end{array}$ & $\begin{array}{c}0.010 \\
(0.008)\end{array}$ & $\begin{array}{c}-0.026^{*} \\
(0.011)\end{array}$ \\
\hline $\begin{array}{l}\text { Works Council } \\
\text { Dummy }\end{array}$ & $\begin{array}{l}-0.348^{* *} \\
(0.126)\end{array}$ & $\begin{array}{c}0.185 \\
(0.202)\end{array}$ & - & U.S. Nominal Tariff & $\begin{array}{c}-0.087 \\
(0.068)\end{array}$ & $\begin{array}{r}0.066^{*} \\
(0.034)\end{array}$ & $\begin{array}{l}0.100^{* *} \\
(0.034)\end{array}$ \\
\hline $\begin{array}{l}\text { Layoff Restriction } \\
\text { Dummy }\end{array}$ & $\begin{array}{l}-0.465^{* *} \\
(0.104)\end{array}$ & $\begin{array}{l}-0.603 * * \\
(0.201)\end{array}$ & - & $\begin{array}{l}\text { U.S. Nominal } \\
\text { Tariff }(+5)\end{array}$ & $\begin{array}{l}0.324 * * \\
(0.063)\end{array}$ & $\begin{array}{c}-0.023 \\
(0.029)\end{array}$ & $\begin{array}{c}-0.057 \\
(0.030)\end{array}$ \\
\hline \multicolumn{4}{|l|}{ F-Test for IR Variables: } & Time Trend & $\begin{array}{l}0.028 * * \\
(0.011)\end{array}$ & $\begin{array}{l}0.044 * * \\
(0.007)\end{array}$ & $\begin{array}{l}0.030^{* *} * \\
(0.008)\end{array}$ \\
\hline F-Statistics (p-value $)^{b}$ & $\begin{array}{l}17.44 * * \\
(0.000)\end{array}$ & $\begin{array}{l}10.54 * * \\
(0.000)\end{array}$ & $\begin{array}{l}0.18 \\
(0.833)\end{array}$ & $\begin{array}{l}\text { Industry Dummy } 1 \\
(\text { Food })^{c}\end{array}$ & $\begin{array}{l}0.347 * * \\
(0.103)\end{array}$ & $\begin{array}{c}-0.044 \\
(0.182)\end{array}$ & - \\
\hline \multicolumn{4}{|l|}{ Control Variables: } & Industry Dummy 2 & $0.885^{* *}$ & $0.393 *$ & - \\
\hline \multirow{2}{*}{$\begin{array}{l}\text { GDP Ratio } \\
\text { (Foreign/U.S.) }\end{array}$} & \multirow{2}{*}{$\begin{array}{l}42.170 * * \\
(2.008)\end{array}$} & \multirow{2}{*}{$\begin{array}{l}34.739 * * \\
(3.656)\end{array}$} & \multirow{2}{*}{$\begin{array}{l}-3.223 \\
(9.266)\end{array}$} & (Chemical) & $(0.138)$ & $(0.187)$ & \\
\hline & & & & Industry Dummy 3 & $0.710 * *$ & 0.072 & - \\
\hline \multirow[t]{2}{*}{ Geographic Distance } & \multirow{2}{*}{$\begin{array}{l}0.113^{* *} \\
(0.012)\end{array}$} & \multirow{2}{*}{$\begin{array}{c}0.063 * \\
(0.026)\end{array}$} & \multirow[t]{2}{*}{ - } & (Metals) & $(0.160)$ & $(0.196)$ & \\
\hline & & & & Industry Dummy 4 & $1.040^{* *}$ & $0.424 *$ & - \\
\hline \multirow[t]{2}{*}{ GDP Ratio $\times$ Distance } & \multirow{2}{*}{$\begin{array}{l}-4.433 * * \\
(0.236)\end{array}$} & \multirow{2}{*}{$\begin{array}{l}-3.425^{* *} \\
(0.450)\end{array}$} & \multirow{2}{*}{$\begin{array}{l}1.211 \\
(1.112)\end{array}$} & (Equip.) & $(0.124)$ & $(0.185)$ & \\
\hline & & & & Industry Dummy 5 & $0.513^{* *}$ & 0.209 & - \\
\hline \multirow[t]{2}{*}{ English Dummy } & \multirow{2}{*}{$\begin{array}{l}-0.764 * * \\
(0.239)\end{array}$} & \multirow{2}{*}{$\begin{array}{c}0.295 \\
(0.223)\end{array}$} & \multirow[t]{2}{*}{-} & (Elect.) & $(0.078)$ & $(0.172)$ & \\
\hline & & & & Industry Dummy 6 & $0.534 * *$ & 0.034 & - \\
\hline \multirow[t]{2}{*}{ GDP Ratio $\times$ English } & \multirow{2}{*}{$\begin{array}{l}8.680 * * \\
(1.164)\end{array}$} & \multirow{2}{*}{$\begin{array}{l}8.401 * * \\
(2.861)\end{array}$} & \multirow{2}{*}{$\begin{array}{c}0.983 \\
(14.664)\end{array}$} & (Transport) & $(0.138)$ & $(0.193)$ & \\
\hline & & & & Constant & $-3.171 * *$ & $-3.117 * *$ & - \\
\hline $\begin{array}{l}\text { PCI Ratio } \\
\text { (Foreign/U.S.) }\end{array}$ & $\begin{array}{l}-2.118^{* *} \\
(0.212)\end{array}$ & $\begin{array}{c}0.133 \\
(0.124)\end{array}$ & $\begin{array}{r}0.308^{*} \\
(0.135)\end{array}$ & & $(0.538)$ & $(0.752)$ & \\
\hline EC Dummy & $\begin{array}{l}0.406^{* *} \\
(0.142)\end{array}$ & $0.548 * *$ & - & $\begin{array}{l}\text { No. of Observations } \\
\text { Box-Cox Lambda }\end{array}$ & $\begin{array}{l}1,218 \\
0.45\end{array}$ & $\begin{array}{l}1,218 \\
0.45\end{array}$ & $\begin{array}{l}1,218 \\
0.45\end{array}$ \\
\hline PCI Ratio $\times$ EC & $\begin{array}{c}(0.142) \\
0.008 \\
(0.168)\end{array}$ & $\begin{array}{c}(0.160) \\
0.062 \\
(0.107)\end{array}$ & $\begin{array}{l}0.175 \\
(0.114)\end{array}$ & LM-Statistics (p-value) & $\begin{array}{l}3.73 \\
(0.053)\end{array}$ & $\begin{array}{l}0.15 \\
(0.698)\end{array}$ & $\begin{array}{l}3.44 \\
(0.063)\end{array}$ \\
\hline PCI Ratio $\times$ English & $\begin{array}{r}0.818^{*} \\
(0.336)\end{array}$ & $\begin{array}{c}0.002 \\
(0.164)\end{array}$ & $\begin{array}{c}0.109 \\
(0.182)\end{array}$ & $\begin{array}{l}\text { Hausman Test }(\text { critical } \\
\text { value }=7.96)\end{array}$ & - & - & $113.48^{* *}$ \\
\hline $\begin{array}{l}\text { Corporate Income } \\
\text { Tax Rate }\end{array}$ & & & & $\begin{array}{l}\text { F Test for Significance of } \\
\text { Fixed Effects (p-value) }\end{array}$ & - & - & $\begin{array}{r}60.04 * * \\
(0.000)\end{array}$ \\
\hline $\begin{array}{l}\text { Tax Rate } \\
\text { Difference } \\
\text { (Foreign - U.S.) }\end{array}$ & $\begin{array}{c}0.387^{*} \\
(0.160)\end{array}$ & $\begin{array}{c}0.010 \\
(0.071)\end{array}$ & $\begin{array}{l}-0.101 \\
(0.076)\end{array}$ & R-Square & 0.80 & 0.75 & 0.98 \\
\hline Earnings-to-Price Ratio & & & & & & & \\
\hline $\begin{array}{l}\text { Difference } \\
\text { (Foreign - U.S.) }\end{array}$ & $\begin{array}{l}2.991 * * \\
(0.657)\end{array}$ & $\begin{array}{c}-0.688^{*} \\
(0.291)\end{array}$ & $\begin{array}{l}-1.163 * * \\
(0.299)\end{array}$ & & & & \\
\hline
\end{tabular}

${ }^{\text {a}}$ Figures in parentheses are standard errors.

${ }^{\mathrm{b}}$ Critical values of the F-test are 2.21 for OLS and random effect models and 3.00 for the fixed effect model.

"Omitted industry is "other."

* Statistically significant at the .05 level; **at the .01 level.

indicate that the GDP ratio and the GDP ratio interacted with geographic distance have substantially larger effect sizes than any of the other covariates. The finding that host country market size is the main determinant of FDI is quite standard, and, as noted by Markusen and Maskus (2001, 2002), it is consistent with "horizontal" MNC models.

Given that our main focus is on the wage 
and IR environment variables, we will comment only briefly on the other control variables. As expected, cultural openness has a positive effect, and corruption a negative effect, on the share of assets or employment located in a host country (although corruption is not statistically significant in the OLS asset equation). The finding that the host country corporate tax rate is positively related to the share of MNC employment located in a host country is surprising, especially given the results of Grubert and Mutti (1991a). As we will see below, however, this result vanishes when we go to a random or fixed effects model. We included four interaction terms in the model that considerably improved fit. ${ }^{16}$ These imply, for instance, that host country GDP and English language are complements in terms of attracting MNC assets. The own coefficient on geographic distance is positive, but the negative interaction with GDP implies that, at the mean of GDP, the effect of distance is negative (that is, according to the OLS estimates, the effect of distance is $0.111-3.685$ ([GDP ratio], and the mean GDP ratio is 0.07 ). Regarding tariffs, note that there is no theoretical prediction, because horizontal MNC models imply that tariffs encourage FDI, while vertical models imply that they discourage it.

Not surprisingly, given past research, the OLS results imply a positive association between the host country average wage in manufacturing and the size of U.S. MNC operations in the country (measured by either assets or employment). The wage coefficient in the employment equation is 1.469 with a standard error of .192. According to the effect size estimates in Table 6 , this implies that a one standard deviation increase in the host country wage would increase the share of MNC worldwide employment allocated to a country by .377 standard deviations. At the mean of the

\footnotetext{
${ }^{16}$ If the four interaction terms are dropped, the Rsquared in the asset equation drops from .78 to .71, while that in the employment equation drops from .80 to .68
}

data, this implies an increase from $1.21 \%$ to $1.79 \%$ - a $48 \%$ increase. Viewed another way, this corresponds to a wage elasticity of demand for labor of positive 0.97 at the mean of the data. ${ }^{17}$ This is clearly an anomalous result.

We turn now to the other key variables of interest in this study, namely, the IR environment measures. The OLS estimates imply that U.S. MNCs prefer to locate production in countries with low strike intensity, decentralized bargaining, and no works councils or layoff restrictions. Host country union density is not statistically significant in either the asset or employment equation. To give an idea of the magnitudes implied by the estimates, in the asset equation, the point estimate for decentralized bargaining (0.117) implies that a one standard deviation increase in the measure of decentralization ( 0.96 points) would increase the share of MNC assets in a particular host country by 0.089 standard deviations (see Table 6 ). This is a 0.11 percentage point increase, which corresponds to a $12 \%$ increase at the mean of the data (recall from Table 1 that the mean percentage of assets in each host country is $0.94 \%$ ).

The OLS results also imply that works councils have very important negative effects. The point estimate of -.569 in the asset equation implies that a shift to having works councils would reduce the share of MNC assets located in a country from $1.28 \%$ to $0.72 \%$ at the mean of the data. This estimate is so large that it may strain credibility. According to the effect size estimates in Table 6, works councils explain the most variation in assets among the IR variables, and the second most variation in employment (being slightly less important than layoff restrictions).

Next, we report estimates of a fixed effects model in which each of the industry/

\footnotetext{
${ }^{17}$ Given our Box-Cox specification, the elasticity of $Y$ with respect to $X$ is given by $\beta \times X \times Y^{\lambda}$. Using the mean wage ratio $(0.72)$, the mean employment share (1.21), and $\lambda=0.45$, this gives the elasticity of 0.97 at the mean of the data.
} 
Table 6. Effect Size. ${ }^{\mathrm{a}}$

\begin{tabular}{|c|c|c|c|c|c|c|c|c|c|}
\hline \multirow[b]{2}{*}{ Variable } & \multicolumn{3}{|c|}{ MOFA Total Asset Ratio } & \multicolumn{3}{|c|}{ MOFA Total Employment Ratio } & \multicolumn{3}{|c|}{ MOFA Net Sales Ratio } \\
\hline & $O L S$ & $\begin{array}{c}\text { Random } \\
\text { Effect }\end{array}$ & $\begin{array}{l}\text { Fixed } \\
\text { Effect }\end{array}$ & $O L S$ & $\begin{array}{c}\text { Random } \\
\text { Effect }\end{array}$ & $\begin{array}{l}\text { Fixed } \\
\text { Effect }\end{array}$ & $O L S$ & $\begin{array}{c}\text { Random } \\
\text { Effect }\end{array}$ & $\begin{array}{l}\text { Fixed } \\
\text { Effect }\end{array}$ \\
\hline Wage Ratio (Foreign/U.S.) & 0.551 & 0.065 & 0.046 & 0.377 & -0.093 & -0.109 & 0.128 & -0.016 & -0.030 \\
\hline Foreign Union Density & -0.043 & -0.036 & -0.031 & -0.053 & -0.022 & -0.017 & -0.014 & -0.015 & -0.016 \\
\hline Foreign Strike Intensity & -0.050 & 0.004 & 0.003 & -0.058 & 0.003 & 0.003 & -0.017 & 0.001 & 0.002 \\
\hline Collective Bargaining Structure & 0.089 & 0.118 & - & 0.048 & 0.098 & - & 0.016 & 0.021 & - \\
\hline Works Council Dummy & -0.225 & -0.016 & - & -0.124 & 0.066 & - & -0.027 & 0.046 & - \\
\hline Layoff Restriction Dummy & -0.027 & -0.095 & - & -0.154 & -0.200 & - & -0.017 & -0.047 & - \\
\hline GDP Ratio (Foreign/U.S.) & 2.463 & 1.851 & -0.335 & 2.504 & 2.063 & -0.191 & 0.711 & 0.480 & -0.191 \\
\hline Geographic Distance & 0.288 & 0.136 & - & 0.268 & 0.150 & - & 0.102 & 0.039 & - \\
\hline GDP Ratio $\times$ Distance & -2.008 & -1.315 & 0.934 & -2.234 & -1.726 & 0.610 & -0.585 & -0.339 & 0.295 \\
\hline English Dummy & -0.176 & 0.161 & - & -0.237 & 0.091 & - & -0.036 & 0.073 & - \\
\hline GDP Ratio $\times$ English & 0.149 & 0.170 & 0.077 & 0.205 & 0.198 & 0.023 & 0.029 & 0.051 & 0.090 \\
\hline PCI Ratio (Foreign/U.S.) & -0.514 & -0.022 & 0.012 & -0.466 & 0.029 & 0.068 & -0.119 & 0.020 & 0.037 \\
\hline EC Dummy & 0.137 & 0.135 & - & 0.146 & 0.197 & - & 0.069 & 0.035 & - \\
\hline PCI Ratio $\times$ EC & 0.073 & 0.150 & 0.179 & 0.002 & 0.016 & 0.046 & -0.012 & 0.045 & 0.056 \\
\hline PCI Ratio $\times$ English & 0.202 & 0.040 & 0.063 & 0.177 & 0.0004 & 0.024 & 0.069 & 0.011 & 0.013 \\
\hline Corporate Income Tax Difference & -0.008 & -0.013 & -0.022 & 0.047 & 0.001 & -0.012 & 0.005 & -0.001 & -0.003 \\
\hline Earnings-to-Price Ratio Difference & 0.111 & 0.017 & 0.005 & 0.074 & -0.017 & -0.029 & 0.024 & -0.003 & -0.008 \\
\hline Cultural Openness & 0.245 & 0.412 & - & 0.107 & 0.236 & - & 0.067 & 0.113 & - \\
\hline Corruption & -0.051 & -0.168 & - & -0.066 & -0.151 & - & -0.013 & -0.057 & - \\
\hline Foreign Nominal Tariff & 0.070 & 0.390 & 0.354 & -0.140 & -0.003 & -0.051 & -0.091 & 0.117 & 0.118 \\
\hline Foreign Nominal Tariff $(+5)$ & -0.117 & -0.370 & -0.685 & 0.177 & 0.099 & -0.256 & 0.087 & -0.110 & -0.190 \\
\hline U.S. Nominal Tariff & -0.028 & 0.072 & 0.095 & -0.074 & 0.057 & 0.085 & 0.023 & 0.018 & 0.023 \\
\hline U.S. Nominal Tariff $(+5)$ & 0.340 & 0.044 & 0.016 & 0.271 & -0.019 & -0.047 & 0.089 & 0.022 & 0.014 \\
\hline Time Trend & 0.105 & 0.110 & 0.085 & 0.058 & 0.091 & 0.062 & 0.057 & 0.049 & 0.043 \\
\hline Industry Dummy 1 (Food) & 0.223 & 0.114 & - & 0.091 & -0.012 & - & 0.059 & 0.025 & - \\
\hline Industry Dummy 2 (Chemical) & 0.365 & 0.219 & - & 0.239 & 0.106 & - & 0.133 & 0.061 & - \\
\hline Industry Dummy 3 (Metals) & 0.203 & 0.028 & - & 0.181 & 0.018 & - & 0.092 & 0.017 & - \\
\hline Industry Dummy 4 (Equip.) & 0.350 & 0.178 & - & 0.269 & 0.110 & - & 0.124 & 0.056 & - \\
\hline Industry Dummy 5 (Elect.) & 0.060 & -0.004 & - & 0.132 & 0.054 & - & 0.039 & 0.006 & - \\
\hline Industry Dummy 6 (Transport) & 0.038 & -0.057 & - & 0.117 & 0.007 & - & 0.042 & -0.011 & - \\
\hline
\end{tabular}

${ }^{a}$ The effect size is calculated using the formula $\beta \bar{Y}^{1-\lambda}\left(\sigma_{x} / \sigma_{y}\right)$, where $\lambda$ is the Box-Cox parameter and $\bar{Y}$ is the mean of the dependent variable. 
country pairs is treated as a cross-sectional unit with its own intercept. By including industry/country-specific intercept terms in the model, the fixed effects specification ignores the cross-sectional covariance of the dependent and independent variables, and identifies the model coefficients purely from the over-time covariance. As a consequence, independent variables that are constant over time (within an industry/ country pair) drop out. This is problematic, because three of the IR variables of interest (decentralized bargaining, works councils, and layoff restrictions) drop out.

The fixed effects estimates are radically different from the OLS estimates. For example, the fixed effects estimates indicate that there is no statistically significant association between the size of U.S. MNCs' operations in a host country, as measured by assets or employment, and host country GDP. This means that as the ratio of host country to U.S. GDP changes over time, the share of U.S. MNCs' assets or employment allocated to that country does not vary significantly. It would, of course, be highly implausible to argue that host country size is not a key determinant of FDI location decisions in the long run. This is an example in which neither OLS nor fixed effects are giving us the "right" answer, but where, instead, each is answering a different question.

The anomalous wage effects noted earlier are no longer present in the fixed effects specification. In the employment equation, the wage coefficient is -.424 with a standard error of .113. This implies that a one standard deviation increase in the host country to U.S. wage ratio would lower the share of MNC employment located in that country by .109 standard deviations (see Table 6). At the mean of the data this implies that a $49 \%$ wage increase would decrease the host country employment share from $1.21 \%$ to $1.04 \%$ - a $14 \%$ decrease. The implied wage elasticity of labor demand is -0.28 . The fact that the wage coefficient switches to the "right" sign when we move from OLS to fixed effects suggests that the potential bias in the wage coefficient resulting from the failure to control for industry/country effects, which we discussed in the introduction, is in fact important.

In the fixed effects asset equation, the wage coefficient is still positive, but much smaller in magnitude and no longer statistically significant. This can be rationalized if substitution and scale effects on MOFAs' demand for capital roughly cancel, so that when host country wages rise MOFAs' capital stocks remain roughly constant. Indeed, Cummins and Hassett (1996) found evidence of strong substitutability between MOFA capital and employment. Thus, once we control for unobserved industry/country effects, the wage coefficient takes on theoretically plausible values in both the asset and employment equations. Hence, it seems likely that unobserved country effects that make high-wage countries desirable places to locate assets drive the large positive effect of wages on employment implied by OLS.

Only two IR environment variablesunion density and strike intensity-are identified in the fixed effects specification, because these are the only two that vary over time. Neither variable is statistically significant in either the asset or employment equation. One concern is potential collinearity between these two variables, such that their separate statistical insignificance conceals joint statistical significance. However, in Table 7 we report correlations of several key variables, and these show that union density and strike intensity are only slightly negatively correlated (-0.069). Moreover, the joint F-tests reported in Tables 4 and 5 show that these IR variables are not jointly statistically significant in either the asset or employment equations. These results imply that there is no statistically significant association between changes in the IR environment in a host country (in terms of union density or strike activity) and changes in the fraction of worldwide assets or employment that U.S. MNCs locate in that country.

The fixed effects results leave no doubt that there are important unmeasured industry/country effects in these data, meaning unmeasured country- and industry-spe- 
cific idiosyncratic factors that make particular countries attractive locations for particular industries. The inclusion of industry/country-specific intercepts causes the $\mathrm{R}^{2}$ for the asset model to increase from .78 to .98 , and that for employment to increase from .80 to .98 . Thus, the unmeasured industry/country effects, which presumably include such things as factor endowments, account for at least $20 \%$ of the variance of U.S. MNCs' decisions about how to allocate assets and employment across various host countries. ${ }^{18}$ The factors we have measured and included in the model, such as GDP, geographic distance, wages, the IR environment, cultural openness, and so on, can account for at most $80 \%$ of the variance. This is actually quite a large proportion of variance to be explained by observables in a cross-country/ cross-industry regression.

The fact that adding industry/countryspecific intercepts substantially improves model fit does not necessarily mean that fixed effects should be the preferred specification. A key issue is whether the unmeasured industry/country effects are correlated with the determinants of MNC production location that we have measured and included in the model. If not, then the fixed effects estimator is inefficient (because it does not exploit the lack of correlation between the unmeasured effects and the regressors), and it needlessly causes loss of identification of the time-invariant regressors. In this case, it may be preferable to use a random effects model.

In the random effects model each industry/country pair is again treated as having its own intercept, in order to capture industry/country-specific unobservables. In the

\footnotetext{
${ }^{18}$ Note that the increase in the R-squared when we include the fixed effects only gives a lower bound on the fraction of variance explained by unobserved time-invariant characteristics of countries. It is of course possible that some portion of the variance "explained" by variables we have measured and included in our models is spurious, meaning that it only arises because these variables are correlated with the excluded unobserved country characteristics.
}

random effects specification, however, the industry/country effects are assumed to be mean independent of the observed covariates. In that case, the unobservables create serial correlation of the residuals within each industry/country pair. Thus, it is appropriate to use a GLS procedure that accounts for the serial correlation in the errors. The random effects estimator, which implements this GLS procedure, is efficient because it optimally weights the information in the cross-sectional and over-time variation in the data. Unlike fixed effects, the random effects estimator does not throw away all the information contained in the cross-sectional variation in the data. However, it in effect down-weights that information relative to OLS, because it recognizes that, due to serial correlation, we do not really have $\mathrm{T}$ independent cross-sectional observations on each industry/country pair.

As we see in Tables 4 and 5 , the fixed and random effects estimates are dramatically different. Most obviously, the random effects estimates imply that GDP, and its interactions with geographic distance and English language, are very important determinants of the share of MNC assets and employment located in a country. At the mean of the data, a $1 \%$ increase in the GDP ratio is predicted to raise the share of MNC assets allocated to a country by $1.36 \%$ if it is English-speaking, and $0.91 \%$ if not. ${ }^{19}$ These appear to be very plausible estimates.

The wage coefficients also appear plausible in both the asset and employment equations. The coefficient on wages is statistically insignificant in the asset equation. In the employment equation the point estimate is -.363 with a standard error of .108. This implies an elasticity of labor demand at the mean of the data of -0.24. Thus, the random effects estimate of the

\footnotetext{
${ }^{19}$ According to the point estimates in Table 4, the elasticity of assets with respect to GDP is given by $[28.71-2.41 \times D+6.35 \times E] \times G \times A^{-0.2}$, where $D, E, G$, and $A$ denote distance, English, GDP ratio, and asset share, respectively. Plugging in means from all variables (see Table 2), we obtain an elasticity of 0.91 if $E$ $=0$ and 1.36 if $E=1$.
} 
Table 7. Correlation Matrix for Selected Variables.

\begin{tabular}{|c|c|c|c|c|c|c|c|}
\hline & $\begin{array}{l}\text { Wage } \\
\text { Ratio }\end{array}$ & $\begin{array}{l}\text { Union } \\
\text { Density }\end{array}$ & $\begin{array}{c}\text { Strike } \\
\text { Intensity }\end{array}$ & $\begin{array}{c}\text { Collective } \\
\text { Bargaining } \\
\text { Structure }\end{array}$ & $\begin{array}{l}\text { Works } \\
\text { Council }\end{array}$ & $\begin{array}{c}\text { Layoff } \\
\text { Restrictions }\end{array}$ & $\begin{array}{c}\text { Cultural } \\
\text { Open- } \\
\text { ness }\end{array}$ \\
\hline Union Density & $\begin{array}{l}0.3185 \\
(0.0000)^{\mathrm{a}}\end{array}$ & & & & & & \\
\hline Strike Intensity & $\begin{array}{l}-0.1479 \\
(0.0000)\end{array}$ & $\begin{array}{c}-0.0688 \\
(0.0131)\end{array}$ & & & & & \\
\hline $\begin{array}{l}\text { Collective Bargaining } \\
\text { Structure }\end{array}$ & $\begin{array}{l}-0.1163 \\
(0.0000)\end{array}$ & $\begin{array}{c}-0.4422 \\
(0.0000)\end{array}$ & $\begin{array}{l}-0.1634 \\
(0.0000)\end{array}$ & & & & \\
\hline Works Councils & $\begin{array}{c}0.2304 \\
(0.0000)\end{array}$ & $\begin{array}{c}0.0859 \\
(0.0019)\end{array}$ & $\begin{array}{c}0.0908 \\
(0.0011)\end{array}$ & $\begin{array}{c}-0.3495 \\
(0.0000)\end{array}$ & & & \\
\hline Layoff Restrictions & $\begin{array}{l}-0.1969 \\
(0.0000)\end{array}$ & $\begin{array}{l}-0.4705 \\
(0.0000)\end{array}$ & $\begin{array}{c}0.2037 \\
(0.0000)\end{array}$ & $\begin{array}{c}0.1601 \\
(0.0000)\end{array}$ & $\begin{array}{c}0.5805 \\
(0.0000)\end{array}$ & & \\
\hline Cultural Openness & $\begin{array}{c}0.0309 \\
(0.2656)\end{array}$ & $\begin{array}{c}-0.0414 \\
(0.1360)\end{array}$ & $\begin{array}{c}-0.0071 \\
(0.7981)\end{array}$ & $\begin{array}{c}-0.1758 \\
(0.0000)\end{array}$ & $\begin{array}{c}-0.0643 \\
(0.0205)\end{array}$ & $\begin{array}{c}0.0462 \\
(0.0959)\end{array}$ & \\
\hline Corruption & $\begin{array}{c}0.1189 \\
(0.0000)\end{array}$ & $\begin{array}{c}0.1467 \\
(0.0000)\end{array}$ & $\begin{array}{l}-0.1733 \\
(0.0000)\end{array}$ & $\begin{array}{l}-0.1588 \\
(0.0000)\end{array}$ & $\begin{array}{l}-0.4743 \\
(0.0000)\end{array}$ & $\begin{array}{c}-0.6263 \\
(0.0000)\end{array}$ & $\begin{array}{r}0.2887 \\
(0.0000)\end{array}$ \\
\hline
\end{tabular}

${ }^{\mathrm{a}}$ Figures in parentheses are p-values.

wage coefficient is similar to the fixed effects estimate, and both are far from the anomalous OLS estimate.

The IR environment variables are not individually statistically significant in the asset equation. However, the joint F-test for these variables is 7.69, which is highly statistically significant. As we see in Table 7 , some moderately high correlations are present among the IR variables. Layoff restrictions and works councils are positively correlated (.58), layoff restrictions and union density are negatively correlated $(-.47)$, and decentralized bargaining is negatively correlated with both union density (-.44) and works councils (-.35). This collinearity does not seem severe, but it complicates sorting out the relative influence of each variable.

Nevertheless, all the point estimates for the IR variables look reasonable in the asset equation. The decentralized bargaining variable comes closest to statistical significance at the $5 \%$ level. Its point estimate is .155 with a standard error of .086 . The point estimate implies that at the mean of the data, a one standard deviation increase in the measure of decentralization $(0.96$ points) would increase the share of MNC assets in a particular host country by 0.118 standard deviations (see Table 6 ). This is a 0.14 percentage point increase, which corresponds to a $15 \%$ increase at the mean of the data (recall that the mean percentage of assets in each host country is $0.94 \%$ ). The point estimates also imply that layoff restrictions are quite important. Their introduction is predicted to reduce the share of MNC assets allocated to a host country from $1.08 \%$ to $0.84 \%$ at the mean of the data-a $23 \%$ reduction.

In the employment equation, the bargaining decentralization and layoff restriction coefficients are individually statistically significant. The point estimate implies that, at the mean of the data, a one standard deviation increase in the measure of decentralization ( 0.96 points) would increase the share of MNC employment allocated to a particular host country by 0.098 standard deviations (see Table 6). This is a 0.15 percentage point increase, which corresponds to a $13 \%$ increase at the mean of the data (recall that the mean percentage of employment in each host country is $1.21 \%)$. The estimated effect of layoff restrictions is larger. At the mean of the data, the point estimates imply that introduction of layoff restrictions would reduce the share of MNG employment allocated to a host 
country from $1.44 \%$ to $0.80 \%$-a $44 \%$ reduction.

The works council variable, which was the most important IR factor according to the OLS estimates, appears to be much less important according to the random effects estimates. In our view, the OLS estimate of the effect of works councils seemed implausibly large, so the random effects estimates seem more credible.

The estimated coefficients of the control variables in the random effects specification also look reasonable. For instance, the estimates imply that cultural openness encourages MNCs to allocate assets and employment to a host country, while corruption discourages FDI. According to the effect size estimates in Table 6 , these are among the more important factors explaining the variation in asset and employment shares across countries.

The disparity between the fixed and random effects estimates leaves us in a quandary as to which specification to prefer. A common way to choose between them is the Durbin-Wu-Hausman (DWH) test. The logic of this test is that, under the null hypothesis that the unit-specific effects are mean independent of the covariates, both the fixed and random effects estimators are consistent (although fixed effects is inefficient because it ignores the cross-sectional covariance in the data). However, under the alternative that correlation is present, the fixed effects estimator remains consistent, while the random effects estimator becomes inconsistent. Thus, the degree of similarity or dissimilarity between the random and fixed effects estimates can be construed as evidence of the extent to which the unmeasured effects are, respectively, uncorrelated with the regressors or correlated with them.

The DWH test statistic values are 74.67 for the asset models and 113.48 for the employment models. Under the null, these statistics are distributed as $\chi^{2}$ random variables with 16 degrees of freedom (since there are 16 common parameters between the fixed and random effects specifications), so the $5 \%$ critical value is 7.96 . Thus, the DWH overwhelmingly rejects the ran- dom effects specification. This outcome is not surprising, since we have already noted the striking differences between the fixed and random effects estimates. It is important to note, however, that this result is not conclusive. The DWH test relies critically on the assumption that any differences between the random effects and fixed effects estimates are due only to correlation between the unit-specific effects and the covariates. In the present context, however, it seems likely that other factors are important.

As we noted earlier, the most striking difference between the random and fixed effects results is that the fixed effects estimates imply that host country GDP is not a statistically significant determinant of U.S. MNC assets and employment allocated to that country. This strikes us as completely implausible. What might account for this result? As long as there are costs to adjusting the level of assets or employment that an MNC maintains in a particular host country, short-run changes in GDP that MNCs perceive as transitory should have little affect on MNC decisions (see Das, Roberts, and Tybout 2001). Thus, it is not at all surprising that the fixed effects estimate of the effect of GDP, which relies exclusively on short-run covariation, would be close to zero. On the other hand, the cross-sectional variation in GDP across host countries is dominated by permanent or longlived differences. If MNCs are responsive to these, as seems likely, then the random effects estimator, which does incorporate the cross-sectional variation in the data, will imply that GDP is an important determinant of MNC decisions.

More generally, the supposition that any difference between the random and fixed effects estimates stems solely from correlation between the unit-specific effects and the covariates relies on the implicit assumption that the dependent variable responds in the same way to permanent and transitory changes in covariates. ${ }^{20}$ This seems

\footnotetext{
${ }^{20}$ Keane and Wolpin (2002) made this point in a different but perfectly analogous context. They con-
} 
highly implausible in the present context. In particular, the same argument we made for why this is not true for GDP applies for aspects of the IR environment as well. For example, suppose strike intensity exhibits substantial permanent differences across countries (very high in Greece and low in Norway, say), and also exhibits transitory variation over time within countries. Given adjustment costs, it is unlikely that a transitory increase in strike activity would lead an MNC to reduce the assets it allocates to a particular host country, even if the MNC's long-run decisions are quite sensitive to the average level of strike activity in a country. ${ }^{21}$

In light of these considerations, we prefer the random effects specification over the fixed effects specification, precisely because we are more interested in the effects of long-lived or permanent differences in wages and the IR environment on MNC location decisions than on the effects of more transitory developments. The random effects specification does have the problem that, if the unit-specific effects are correlated with the covariates, the estimates may be inconsistent. However, to counter this concern, we appeal to the fact that we have included quite a rich set of control

sidered a model of welfare program participation in which single mothers are eligible for welfare benefits until their child reaches age 18 . In the model, women's decisions about whether to become single mothers depend on the average level of welfare benefits they expect to prevail during the period until a child reaches 18 . Hence, their decisions are quite insensitive to transitory fluctuations in benefits. Using simulated data from this model, Keane and Wolpin showed that a fixed effects model falsely implies that women's decisions about whether to become single mothers are insensitive to welfare benefits. As Keane and Runkle (1992) discussed, another reason for differences between the random and fixed effects estimators is failure of the strict exogeneity assumption that underlies both estimators. If that assumption fails, then both are inconsistent, and the DWH test is uninformative.

${ }^{21}$ It is interesting that the random and fixed effects estimates of the wage coefficient are quite close. This could be rationalized if the labor input is indeed quite variable in the short run (in contrast to capital). In that case, the responses of employment to permanent and transitory wage changes may not differ greatly. variables in our models. Indeed, the fraction of variance explained by our measured covariates $(78-80 \%)$ is very high relative to levels achieved in most panel data studies. Thus, unobserved unit-specific effects may be a less important source of bias here than they often are in panel data work. We also appeal to the fact that our random effects estimates have considerable face validity. This is the only specification in which all the statistically significant estimated coefficients have quite reasonable signs and magnitudes.

In summary, our preferred random effects estimates support a conclusion that both wages and the IR environment are important determinants of U.S. MNCs' production location decisions. While some mild collinearity problems make it difficult to sort out the relative importance of all the IR factors we have examined, the clearest evidence seems to be that U.S. MNCs prefer to locate assets and employment in host countries with decentralized bargaining structures and with no important restrictions on layoffs.

We have reserved until now any detailed discussion of the tariff coefficients. In the random effects specification, the current U.S. and host country tariff coefficients are statistically significant and positive in the asset equation, and the current U.S. tariff coefficient is statistically significant and positive in the employment equation. The fixed effects results are similar. Thus, there is no support for the notion that tariff reductions increase FDI. The failure to find statistically significant positive effects of trade liberalization on FDI is consistent with the finding that market access ("jumping tariff walls") is the main factor driving FDI (the horizontal model).

Theory suggests that the vertical model should better explain FDI in relatively lowwage countries like Mexico, while the horizontal model should better explain FDI in high-wage countries (which account for most U.S. FDI). Thus, interactions between tariffs and wages should be important. That is, higher tariffs should encourage FDI in high-wage countries while discouraging FDI in low-wage countries, lead- 
ing to a negative linear coefficient on tariffs and a positive coefficient on the interaction with the host country wage rate. When we included such interactions, they were completely statistically insignificant in the asset equation. But the expected sign pattern did emerge in the employment equation (although magnitudes of the negative linear terms were small). This result is consistent with the notion that trade liberalization with a single low-wage country like Mexico, where FDI is more likely to be motivated by factor price differentials, would lead to an increased share of U.S. MNCs' employment being located in that country. However, if trade liberalization is a worldwide trend, we would expect, given our results, that it would reduce the overall share of U.S. MNCs' employment located abroad.

Finally, in Appendix Table A3 we report results for net sales for the sake of comparability with several earlier studies that examined this variable. The results are broadly similar to our results for assets and employment. OLS estimates imply that the size of $\mathrm{MNC}$ operations in a host country as measured by net sales is strongly positively related to the host country wage rate. But this anomalous finding is reversed when we control for unobserved country/industry effects using either a random or fixed effects specification. OLS and random effects estimates imply that host country GDP is the major factor driving MNC location decisions, while the fixed effects estimates produce the implausible result that host country market size is unimportant. The set of IR environment variables is not jointly statistically significant in the net sales equation, but as we noted in the introduction, we view the net sales results as relatively uninformative, because sales equal price times quantity. Thus, how the covariates affect sales does not tell us directly how those covariates affect the scale of MNC operations.

\section{Conclusion}

We have examined the production location decisions of U.S. MNCs, using BEA industry level data on U.S. MNC operations in 22 countries over 10 years (1982-91). Four main conclusions emerge.

First, we find evidence that the IR environment does have statistically significant effects on U.S. MNCs' production location decisions. U.S. MNCs prefer to locate production in foreign host countries with a decentralized bargaining structure and without appreciable restrictions on layoffs. Our preferred random effects model estimates imply that if a host country is one standard deviation above average in terms of our measure of decentralization, the share of U.S. MNC assets allocated to that country will be, ceteris paribus, $15 \%$ higher. The corresponding figure for employment is also $15 \%$. Our estimates imply that the introduction of important layoff restrictions would, ceteris paribus, reduce the shares of assets and employment allocated to a particular host country by $23 \%$ and $44 \%$, respectively. Other features of the IR environment, like union density, strike intensity, and works councils, do not appear to be as important.

Second, we conclude that the prior literature's dominant and anomalous finding of a positive or zero association between a host country's wage rate and MNCs' allocation of employment to the country is due largely to the tendency to identify the wage coefficient purely from cross-sectional variation, and the failure to control for industry/country-specific unobservables. Indeed, we find that wage coefficients in models for MNCs' allocation of employment to a country switch sign from positive to negative when we control for industry/ country effects using either a random effects or fixed effects specification. Thus, contrary to most prior studies, we find that U.S. MNCs do prefer to locate employment in low-wage countries, ceteris paribus. Our preferred random effects estimates imply that the elasticity of employment with respect to host country wages is -0.24 .

Third, while we find that both wages and the IR environment are important, it is worth emphasizing that by far the most important determinant of MNC production location decisions appears to be sim- 
ply host country GDP (that is, market size). This finding is consistent with horizontal models of MNCs. Other variables with statistically significant influence were cultural openness, corruption, geographic distance, corporate tax rates, and tariffs. Our complete set of covariates explains a very large share of the variation in U.S. MNCs' production allocation across countries (with the R-squared values in our asset and employment equations being $78-80 \%$ ).

Fourth, we find no evidence that tariff reductions would lead to significant increases in the share of U.S. MNC assets and employment located abroad. In fact, our estimates imply the reverse. This is again consistent with the horizontal MNC model, in which market access is the main factor driving FDI, so that tariff reductions actually discourage FDI. The concern-frequently expressed in the debate over NAFTA-that trade liberalization would lead to an increased share of MNC employment being located abroad may be exag- gerated, since the vertical model, in which the exploitation of factor price differentials drives FDI, explains a relatively small part of FDI.

The key importance of stable factors like relative market size implies that trade liberalization is unlikely to lead to any sudden and substantial shifts of U.S. MNC operations toward countries with lower wages or more favorable IR environments, despite our findings that these factors are important. As further evidence for this conclusion, we also found that the allocation of U.S. MNC operations across host countries changed little between 1982 and 1991, despite the tariff reductions in the Tokyo round of the GATT that took effect from 1982 though 1987. Thus, it appears that the allocation of U.S. MNC operations (that is, capital and employment) across foreign countries and the U.S. has been in something close to an equilibrium position for many years, and that the factors we consider are only leading to small and gradual shifts in that equilibrium. 
Appendix Table A1

Industrial Relations Environment Indicators

\begin{tabular}{|c|c|c|c|c|c|}
\hline Country & $\begin{array}{c}\text { Union } \\
\text { Density } \\
\text { (Averaged } \\
\text { over 1982-91) }\end{array}$ & $\begin{array}{c}\text { Strike } \\
\text { Intensity } \\
\text { (Averaged } \\
\text { over 1982-91) }\end{array}$ & $\begin{array}{c}\text { Degree } \\
\text { of } \\
\text { Bargaining } \\
\text { Decentralization }\end{array}$ & $\begin{array}{c}\text { Works } \\
\text { Councils }\end{array}$ & $\begin{array}{c}\text { Layoff } \\
\text { Restriction }\end{array}$ \\
\hline Australia & 55.43 & 252 & 2 & 0 & 0 \\
\hline Austria & 61.43 & 7 & 0 & 1 & 0 \\
\hline Belgium & 54.60 & 45 & 2 & 1 & 0 \\
\hline Canada & 35.20 & 428 & 4 & 0 & 0 \\
\hline Denmark & 76.00 & 143 & 1.33 & 1 & 0 \\
\hline France & 15.77 & 64 & 1 & 1 & 1 \\
\hline Germany & 36.07 & 31 & 1.67 & 1 & 0 \\
\hline Greece & 32.40 & 3,630 & 0 & 1 & 1 \\
\hline Ireland & 61.67 & 318 & 1.67 & 0 & 0 \\
\hline Italy & 43.63 & 492 & 2.67 & 1 & 1 \\
\hline Japan & 28.93 & 8 & 3 & 0 & 0 \\
\hline Korea & 14.97 & 306 & 4 & 1 & 1 \\
\hline Mexico & 29.00 & 218 & 3 & 0 & 0 \\
\hline Netherlands & 29.67 & 20 & 1.67 & 1 & 1 \\
\hline New Zealand & 48.13 & 386 & 2 & 0 & 0 \\
\hline Norway & 56.57 & 100 & 1 & 1 & 0 \\
\hline Portugal & 46.80 & 106 & 2 & 1 & 1 \\
\hline Singapore & 22.43 & 0 & 1 & 0 & 0 \\
\hline Spain & 18.00 & 582 & 2 & 1 & 1 \\
\hline Sweden & 83.10 & 83 & 1 & 0 & 0 \\
\hline Switzerland & 28.50 & 5 & 3 & 0 & 0 \\
\hline United Kingdom & 45.90 & 272 & 2.67 & 0 & 0 \\
\hline
\end{tabular}

Note: For strike intensity we report days lost per thousand workers, but days lost per worker is included in the regressions. 
Appendix Table A2

LM Heteroskedasticity Test Statistics under Alternative Box-Cox Transformations

\begin{tabular}{|c|c|c|c|c|c|c|c|c|c|}
\hline \multirow{2}{*}{$\begin{array}{l}\quad \text { Dependent } \\
\quad \text { Variable } \\
\text { Box-Cox } \\
\text { Transform } \\
\text { Parameter }\end{array}$} & \multicolumn{3}{|c|}{ Asset Share } & \multicolumn{3}{|c|}{ Employment Share } & \multicolumn{3}{|c|}{ Net Sales Share } \\
\hline & $O L S$ & $\begin{array}{l}\text { Fixed } \\
\text { Effects } \\
\text { Model }\end{array}$ & $\begin{array}{c}\text { Random } \\
\text { Effects } \\
\text { Model }\end{array}$ & $O L S$ & $\begin{array}{l}\text { Fixed } \\
\text { Effects } \\
\text { Model }\end{array}$ & $\begin{array}{c}\text { Random } \\
\text { Effects } \\
\text { Model }\end{array}$ & $O L S$ & $\begin{array}{l}\text { Fixed } \\
\text { Effects } \\
\text { Model }\end{array}$ & $\begin{array}{c}\text { Random } \\
\text { Effects } \\
\text { Model }\end{array}$ \\
\hline 1.0 & $\begin{array}{l}209.86 \\
\quad(0.000)\end{array}$ & $\begin{array}{l}318.69 \\
(0.000)\end{array}$ & $\begin{array}{l}216.12 \\
\quad(0.000)\end{array}$ & $\begin{array}{l}68.55 \\
(0.000)\end{array}$ & $\begin{array}{l}209.63 \\
(0.000)\end{array}$ & $\begin{array}{l}64.90 \\
(0.000)\end{array}$ & $\begin{array}{r}143.57 \\
(0.000)\end{array}$ & $\begin{array}{l}301.13 \\
\quad(0.000)\end{array}$ & $\begin{array}{c}134.17 \\
\quad(0.000)\end{array}$ \\
\hline 0.9 & $\begin{array}{c}102.87 \\
(0.000)\end{array}$ & $\begin{array}{l}253.28 \\
(0.000)\end{array}$ & $\begin{array}{c}102.34 \\
(0.000)\end{array}$ & $\begin{array}{l}39.05 \\
(0.000)\end{array}$ & $\begin{array}{c}181.33 \\
(0.000)\end{array}$ & $\begin{array}{l}35.03 \\
(0.000)\end{array}$ & $\begin{array}{c}135.48 \\
(0.000)\end{array}$ & $\begin{array}{l}294.01 \\
(0.000)\end{array}$ & $\begin{array}{c}115.71 \\
(0.000)\end{array}$ \\
\hline 0.8 & $\begin{array}{l}54.45 \\
(0.000)\end{array}$ & $\begin{array}{c}190.92 \\
(0.000)\end{array}$ & $\begin{array}{l}56.82 \\
(0.000)\end{array}$ & $\begin{array}{l}28.35 \\
(0.000)\end{array}$ & $\begin{array}{l}152.85 \\
(0.000)\end{array}$ & $\begin{array}{l}26.07 \\
(0.000)\end{array}$ & $\begin{array}{l}104.85 \\
(0.000)\end{array}$ & $\begin{array}{l}239.47 \\
\quad(0.000)\end{array}$ & $\begin{array}{l}87.21 \\
(0.000)\end{array}$ \\
\hline 0.7 & $\begin{array}{l}13.66 \\
(0.000)\end{array}$ & $\begin{array}{c}114.72 \\
(0.000)\end{array}$ & $\begin{array}{l}16.38 \\
(0.000)\end{array}$ & $\begin{array}{l}15.16 \\
(0.000)\end{array}$ & $\begin{array}{l}113.34 \\
(0.000)\end{array}$ & $\begin{array}{l}15.49 \\
(0.000)\end{array}$ & $\begin{array}{l}65.59 \\
(0.000)\end{array}$ & $\begin{array}{l}168.13 \\
\quad(0.000)\end{array}$ & $\begin{array}{l}51.97 \\
(0.000)\end{array}$ \\
\hline 0.6 & $\begin{array}{c}0.11 \\
(0.739)\end{array}$ & $\begin{array}{l}39.21 \\
(0.000)\end{array}$ & $\begin{array}{c}0.01 \\
(0.908)\end{array}$ & $\begin{array}{c}3.32 \\
(0.068)\end{array}$ & $\begin{array}{l}63.37 \\
(0.000)\end{array}$ & $\begin{array}{l}5.54 \\
(0.019)\end{array}$ & $\begin{array}{l}26.05 \\
(0.000)\end{array}$ & $\begin{array}{l}88.75 \\
(0.000)\end{array}$ & $\begin{array}{l}18.22 \\
(0.000)\end{array}$ \\
\hline 0.5 & $\begin{array}{l}11.06 \\
(0.001)\end{array}$ & $\begin{array}{l}1.02 \\
(0.314)\end{array}$ & $\begin{array}{l}8.68 \\
(0.003)\end{array}$ & $\begin{array}{c}0.53 \\
(0.469)\end{array}$ & $\begin{array}{l}16.55 \\
(0.000)\end{array}$ & $\begin{array}{c}0.24 \\
(0.622)\end{array}$ & $\begin{array}{c}2.87 \\
(0.090)\end{array}$ & $\begin{array}{l}24.41 \\
(0.000)\end{array}$ & $\begin{array}{l}0.80 \\
(0.372)\end{array}$ \\
\hline 0.45 & $\begin{array}{l}15.81 \\
(0.000)\end{array}$ & $\begin{array}{l}1.69 \\
(0.193)\end{array}$ & $\begin{array}{l}13.51 \\
(0.000)\end{array}$ & $\begin{array}{c}3.73 \\
(0.053)\end{array}$ & $\begin{array}{l}3.44 \\
(0.063)\end{array}$ & $\begin{array}{c}0.15 \\
(0.698)\end{array}$ & $\begin{array}{l}0.05 \\
(0.817)\end{array}$ & $\begin{array}{c}6.71 \\
(0.010)\end{array}$ & $\begin{array}{c}0.38 \\
(0.536)\end{array}$ \\
\hline 0.4 & $\begin{array}{l}15.68 \\
(0.000)\end{array}$ & $\begin{array}{l}8.84 \\
(0.003)\end{array}$ & $\begin{array}{l}14.12 \\
(0.000)\end{array}$ & $\begin{array}{c}8.21 \\
(0.004)\end{array}$ & $\begin{array}{l}0.02 \\
(0.887)\end{array}$ & $\begin{array}{l}1.20 \\
(0.273)\end{array}$ & $\begin{array}{l}0.59 \\
(0.441)\end{array}$ & $\begin{array}{l}0.23 \\
(0.628)\end{array}$ & $\begin{array}{c}3.07 \\
(0.079)\end{array}$ \\
\hline 0.3 & $\begin{array}{c}4.90 \\
(0.027)\end{array}$ & $\begin{array}{l}12.88 \\
(0.000)\end{array}$ & $\begin{array}{c}5.27 \\
(0.022)\end{array}$ & $\begin{array}{l}10.72 \\
(0.001)\end{array}$ & $\begin{array}{c}2.61 \\
(0.106)\end{array}$ & $\begin{array}{c}2.56 \\
(0.110)\end{array}$ & $\begin{array}{c}0.63 \\
(0.429)\end{array}$ & $\begin{array}{l}2.00 \\
(0.157)\end{array}$ & $\begin{array}{c}5.23 \\
(0.022)\end{array}$ \\
\hline 0.2 & $\begin{array}{l}0.67 \\
(0.412)\end{array}$ & $\begin{array}{l}0.14 \\
(0.708)\end{array}$ & $\begin{array}{l}0.09 \\
(0.763)\end{array}$ & $\begin{array}{l}2.71 \\
(0.100)\end{array}$ & $\begin{array}{c}2.87 \\
(0.09)\end{array}$ & $\begin{array}{c}0.49 \\
(0.482)\end{array}$ & $\begin{array}{c}2.64 \\
(0.104)\end{array}$ & $\begin{array}{c}3.33 \\
(0.068)\end{array}$ & $\begin{array}{c}0.22 \\
(0.635)\end{array}$ \\
\hline 0.1 & $\begin{array}{l}16.03 \\
(0.000)\end{array}$ & $\begin{array}{l}19.42 \\
(0.000)\end{array}$ & $\begin{array}{c}9.48 \\
(0.002)\end{array}$ & $\begin{array}{c}0.98 \\
(0.321)\end{array}$ & $\begin{array}{l}51.94 \\
(0.000)\end{array}$ & $\begin{array}{l}1.18 \\
(0.278)\end{array}$ & $\begin{array}{l}23.64 \\
(0.000)\end{array}$ & $\begin{array}{l}68.32 \\
(0.000)\end{array}$ & $\begin{array}{c}6.53 \\
(0.011)\end{array}$ \\
\hline $\log (y)$ & $\begin{array}{l}44.79 \\
(0.000)\end{array}$ & $\begin{array}{l}61.60 \\
(0.000)\end{array}$ & $\begin{array}{l}33.19 \\
(0.000)\end{array}$ & $\begin{array}{l}12.04 \\
(0.001)\end{array}$ & $\begin{array}{c}139.48 \\
(0.000)\end{array}$ & $\begin{array}{l}9.09 \\
(0.003)\end{array}$ & $\begin{array}{l}51.59 \\
(0.000)\end{array}$ & $\begin{array}{c}143.12 \\
(0.000)\end{array}$ & $\begin{array}{l}30.06 \\
(0.000)\end{array}$ \\
\hline
\end{tabular}

Note: p-values are in parentheses. 
Appendix Table A3

Majority-Owned Foreign Affiliates' Net Sales Ratio

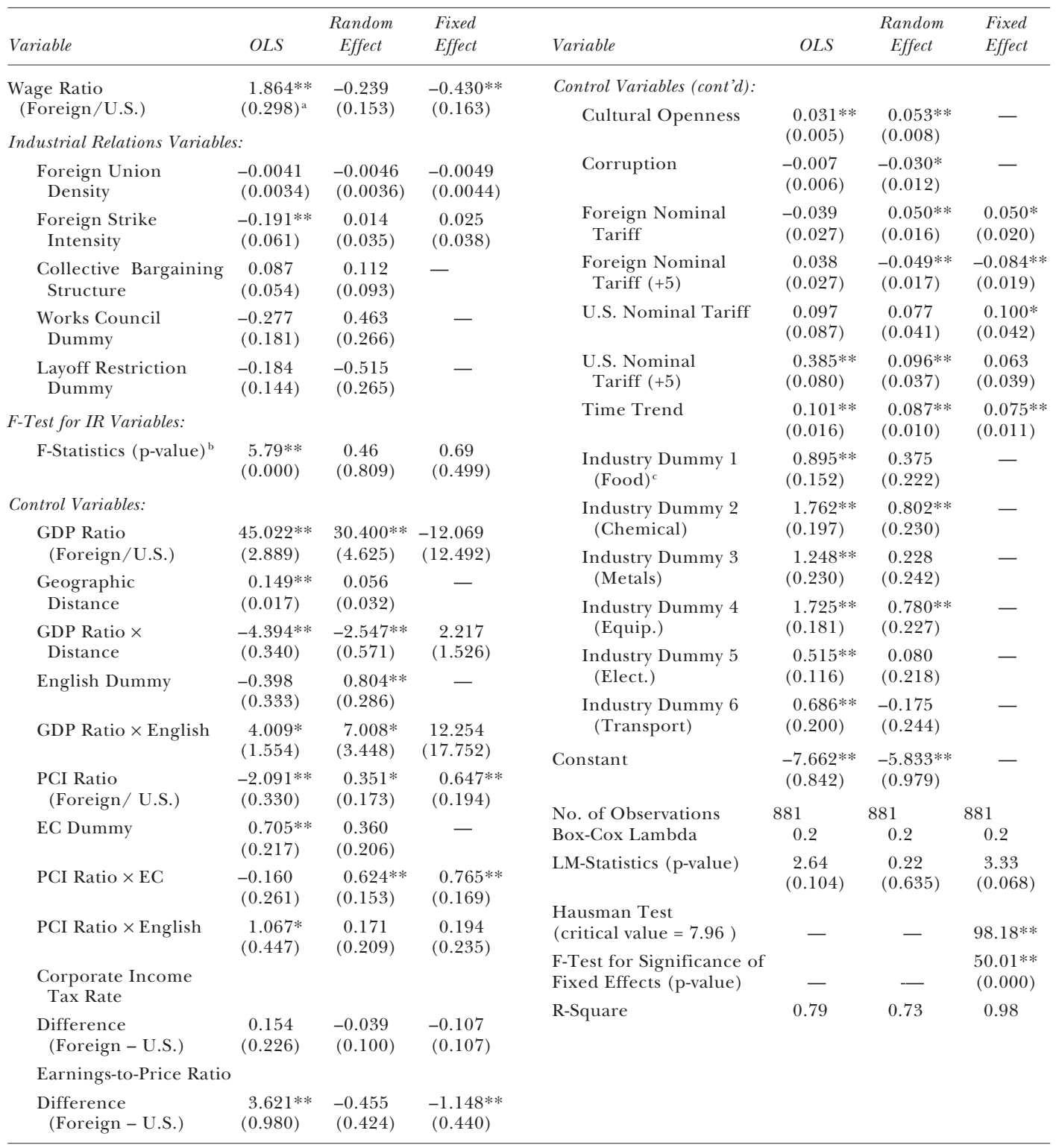

${ }^{a}$ Figures in parentheses are standard errors.

${ }^{\mathrm{b}}$ Critical values of the F-test are 2.21 for OLS and random effect models and 3.00 for the fixed effect model.

'Omitted industry is "other."

*Statistically significant at the .05 level; **at the .01 level. 


\section{REFERENCES}

Anderson, Mark A. 1993. "North American Free Trade Agreement's Impact on Labor." In Mario Bognanno and Katherine Ready, eds., The North American Free Trade Agreement: Labor, Industry, and Government Perspectives. Westport, Conn., and London: Praeger, pp. 55-60.

Betcherman, Gordon. 1993. Labor in a More Global Economy. Ottawa: Human Resources and Labour Canada.

Brainard, Lael S. 1995. "Comment on R. Lipsey: Outward Direct Investment and the U.S. Economy." In Martin Feldstein, James R. Hines, Jr., and R. Glenn Hubbard, eds., The Effects of Taxation on Multinational Corporations. Chicago: University of Chicago Press, pp. 33-41.

Calmfors, Lars, and John Driffill. 1988. "Bargaining Structure, Corporatism, and Macroeconomic Performance." Economic Policy, Vol. 6, pp. 14-61.

Carlton, Dennis. 1979. "Why New Firms Locate Where They Do: An Econometric Model." In W. Wheaton, ed., Interregional Movements and Regional Growth. Washington, D.C.: The Urban Institute, pp. 13-50.

Commission of the European Communities. 1994. Social Europe: The Regulation of Working Conditions in the Member States of the European Community. Vol. 2, Suppl. 5/93, Luxembourg.

Cooke, William N. 1997. "The Influence of Industrial Relations Factors on U.S. Direct Investment Abroad." Industrial and Labor Relations Review, Vol. 51, No. 1 (October), pp. 3-17.

2001. "The Effects of Labour Costs and Workplace Constraints on Foreign Direct Investment among Highly Industrialized Countries." International Journal of Human Resource Management, Vol. 12, No. 5 (August), pp. 697-716.

Cooke, William N., and Deborah S. Noble. 1998. "Industrial Relations Systems and U.S. Foreign Direct Investment Abroad." British Journal of Industrial Relations, Vol. 36, No. 4 (December), pp. 581-609.

Culem, Claudy G. 1988. "The Locational Determinants of Direct Investments among Industrialized Countries.” European Economic Review, Vol. 32, No. 4 (April), pp. 885-904.

Cummins, Jason G., and Kevin A. Hassett. 1996. "The Giant Sucking Sound: Structural Estimates of Factor Substitution from Firm-Level Panel Data on Multinational Corporations." Working Paper, New York University.

Cummins, Jason G., Trevor S. Harris, and Kevin A. Hassett. 1995. "Accounting Standards, Information Flow, and Firm Investment Behavior." In Martin Feldstein, James R. Hines, Jr., and R. Glenn Hubbard, eds., The Effects of Taxation on Multinational Corporations. Chicago: University of Chicago Press, pp. 181-223.

Cummins, Jason G., and R. Glenn Hubbard. 1995. "The Tax Sensitivity of Foreign Direct Investment: Evidence from Firm-Level Panel Data." In Martin Feldstein, James R. Hines, Jr., and R. Glenn Hubbard, eds., The Effects of Taxation on Multinational Corpora- tions. Chicago: University of Chicago Press, pp. 123-52.

Das, Sanghamitra, Mark Roberts, and James Tybout. 2001. "Market Entry Costs, Producer Heterogeneity, and Export Dynamics." NBER Working Paper No. 8629 .

Devereux, Michael, and Rachel Griffith. 1996. "Taxes and the Location of Production: Evidence from a Panel of U.S. Multinationals." Journal of Public Economics, Vol. 68, No. 3 (June), pp. 335-67.

Dunning, John. 1975. Economic Analysis and the Multinational Enterprise. New York: Praeger. 1980. "Toward an Eclectic Theory of International Production: Some Empirical Tests." Journal of International Business Studies, Vol. 11, No. 1 (Spring/Summer), pp. 9-31.

Erickson, Christopher L., and Sarosh Kuruvilla. 1994. "Labor Costs and the Social Dumping Debate in the European Union." Industrial and Labor Relations Review, Vol. 48, No. 1 (October), pp. 28-47.

Feinberg, Susan, and Michael Keane. 2001. "USCanada Trade Liberalization and MNC Production Location." Review of Economics and Statistics, Vol. 83, No. 1 (February), pp. 118-32.

2003. "Accounting for the Growth of MNCBased Trade Using a Structural Model of U.S. MNCs.” Working paper, Yale University.

Feinberg, Susan, Michael Keane, and Mario Bognanno. 1998. "Trade Liberalization and 'Delocalization': New Evidence from Firm Level Panel Data." Canadian Journal of Economics, Vol. 31, No. 4 (November), pp. 749-77.

Fitzpatrick, Gary L., and Marilyn J. Modlin. 1986. Direct-Line Distances. Metuchen, N.J.: Scarecrow Press.

Grubert, Harry, and John Mutti. 1991a. "Taxes, Tariffs, and Transfer Pricing in Multinational Corporate Decision-Making." Review of Economics and Statistics, Vol. 73, No. 2 (May), pp. 285-93.

1991b. "Financial Flows versus Capital Spending: Alternative Measures of U.S.-Canadian Investment and Trade in the Analysis of Taxes." In Peter Hooper and J. David Richardson, eds., International Economic Transactions. Chicago: University of Chicago Press, pp. 293-320.

Hausman, Jerry. 1978. "Specification Tests in Econometrics." Econometrica, Vol. 46, No. 6 (November), pp. 1251-71.

Hymer, Stephen. 1976. The International Operations of National Firms: A Study of Foreign Direct Investment. Cambridge, Mass.: MIT Press.

ILO (International Labour Office). 1995. Yearbook of Labor Statistics. Geneva, Switzerland: International Labour Office.

IMD (International Institute for Management Development). 1990. The World Competitiveness Report, 1990. Cologny/Geneva, Switzerland: IMD International and World Economic Forum.

1992. The World Competitiveness Report, 1992. Cologny/Geneva, Switzerland: IMD International and World Economic Forum. 
IMF (International Monetary Fund). 1982-1992. International Financial Statistics Yearbook. Washington, D.C.: International Monetary Fund.

Karier, Thomas. 1995. "U.S. Foreign Production and Unions." Industrial Relations, Vol. 34, No. 1 (January), pp. 107-18.

Keane, Michael P., and David E. Runkle. 1992. "On the Estimation of Panel Data Models with Serial Correlation When Instruments Are Predetermined but Not Strictly Exogenous." Journal of Business and Economic Statistics, Vol. 10, No. 1 (January), pp. 1-9. Also in G. S. Maddala, ed., The Econometrics of Panel Data (Cheltenham: Edward Elgar).

Keane, Michael P., and Kenneth I. Wolpin. 2002. "Estimating Welfare Effects Consistent with Forward Looking Behavior, Part I: Lessons from a Simulation Exercise." Journal of Human Resources, Vol. 37, No. 3 (Summer), pp. 570-99.

Kleiner, Morris, and Chang-Ruey Ay. 1996. "Unionization, Employee Representation, and Economic Performance: Comparisons among OECD Nations." In Advances in Industrial and Labor Relations, Vol. 7. Greenwich, Conn.: JAI Press, pp. 97-121.

Kleiner, Morris, and Hwikwon Ham. 2003. "The Effect of Different Industrial Relations Systems in the Unites States and the European Union on Foreign Direct Investment Flows." In William N. Cooke, ed., Multinational Companies and Global Resource Strategies. Westport, Conn.: Quorum, pp. 87-97.

Kowalczyk, Carsten, and Donald Davis. 1998. "Tariff Phase-Outs: Theory and Evidence from GATT and NAFTA." In Jeffrey Frankel, ed., Regionalization of the World Economy. Chicago: University of Chicago Press and NBER, pp. 227-58.

Markusen, James, and Keith Maskus. 2001. "Multinational Firms: Reconciling Theory and Evidence." In Magnus Blomstrom and Linda Goldberg, eds., Topics in Empirical InternationalEconomics: A Festschrift in Honor of Robert Lipsey. Chicago: University of Chicago Press, pp. 71-95.

2002. "Discriminating among Alternative Theories of the Multinational Enterprise." Review of International Economics, Vol. 10, No. 4 (November), pp. 694-707.

Morgan Stanley Capital International. 1995. Earnings-to-Price Ratio. Unpublished Data.

OECD. 1982-1992. National Accounts-Main Aggregates. Paris: Organisation for Economic Co-operation and Development.

Robinson, Ian. 1994. "How Will the North American Free Trade Agreement Affect Worker Rights in North America?" In Maria L. Cook and Harry C. Katz, eds., Regional Integration and Industrial Relations in North
America. Ithaca, N.Y.: Institute of Collective Bargaining, New York State School of Industrial and Labor Relations, Cornell University, pp. 105-31.

Rothman, Miriam, Dennis R. Briscoe, and Raoul C.D. Nacamulli. 1993. Industrial Relations around the World. New York: Walter de Gruyter.

Rugman, Alan M. 1985. The Determinants of IntraIndustry Direct Foreign Investment. New York: St. Martin's.

Stevens, Guy V. G. 1972. "Capital Mobility and the International Firm.” In Fritz Machlup, Walter Salant, and Lorie Tarshis, ed., International Mobility and Movement of Capital. New York: Columbia University Press.

Swedenborg, Birgitta. 1979. The Multinational Operations of Swedish Firms. Stockholm, Sweden: Almqvist \& Wiksell International.

Torriente, Anna L. 1997. Mexican and U.S. Labor Law and Practice: A Practical Guide for Maquilas and Other Businesses. Tucson, Arizona: National Law Center for Inter-American Free Trade.

U.K. Department of Labor. 1992. Employment Gazette, Vol. 102. United Kingdom.

Ulman, Lloyd. 1975. "Multinational Unionism: Incentives, Barriers, and Alternatives." Industrial Relations, Vol. 14 (February), pp. 1-31.

United Nations Conference on Trade and Development. 1982-1993. Handbook of International Trade and Development Statistics.

U.S. Department of Commerce, Bureau of Economic Analysis. 1985-94. U.S. Direct Investment AbroadAnnual and Benchmark Survey Data. Washington, D.C.

1985. U.S. Direct Investment Abroad, 1982 Benchmark Survey Data. Washington, D.C.

U.S. Department of Commerce. 1995. U.S. Exports and Imports of Merchandise. CD-ROM.

U.S. Department of Labor. 1990. International Comparisons of Hourly Compensation Costs for Production Workers in Manufacturing, 1989. Washington, D.C.: Bureau of Labor Statistics.

1992. Foreign Labor Trends. Washington, D.C.: Bureau of Labor Statistics.

1993. International Comparisons of Hourly Compensation Costs for Production Workers in Manufacturing, 1992. Washington, D.C.: Bureau of Labor Statistics.

Visser, Jelle. 1991. "Trends in Trade Union Membership." In Employment Outlook, 1991. Paris: Organization for Economic Co-operation and Development, pp. 97-134.

WTO. 1995. International Data Base CD ROM. World Trade Organization. 
Copyright of Industrial \& Labor Relations Review is the property of Cornell University and its content may not be copied or emailed to multiple sites or posted to a listserv without the copyright holder's express written permission. However, users may print, download, or email articles for individual use. 